\title{
El programa vital de San Agustín
}

\author{
Deum et animam scire cupio. Nihilne \\ plus? Nihil omnino. (Sol. I, 2,7). \\ Noverim me, noverim te. (Sol. II, 1,1)
}

Adquirir la certeza de que el alma es inmortal y descubrir las vías que conducen a Dios, no sólo para averiguar si realmente existe, sino principalmente para conseguir la felicidad con su conocimiento y posesión, es decir, viéndole y amándole, he ahi el programa vital de San Agustín que, planteado en los primeros días de su conversión, desarrolló sin descanso hasta su muerte en su vida mística, con su ciencia teológica y mediante sus reflexiones filosóficas.

La fe cristiana, don del Cielo que había recibido, le instruía con certeza plena sobre estos asuntos, y sabía que le bastaban los avisos de la fe para llegar a la felicidad anhelada; pero también sabía que es bueno añadir a la fe crédula la inteligencia sabia en la medida que ello sea posible. Por eso se esforzó siempre en esclarecer con las luces de la filosofía aquello mismo que, con certeza, pero envuelto en misterios le presentaba la fe; e hizo esto con alegre conflanza, sabiendo de antemano que las luces de la fe no contrarían las de la inteligencia. Al contrario, ambos resplandores se acrecientan mutuamente. "Entiende para que creas mi palabra; cree para que entiendas la palabra de Dios" ". Con esto, a la vez que satisfacia sus naturales ansias de saber, se preparaba para dar razón cumplida de su fe y ayudaba a los no creyentes.

Conocer y amar a Dios, al alma, y a los hombres en cuanto tienen alma racional es el programa íntegro de todas las actividades de Agustín para toda su vida. Nos interesa ahora hacer algunas reflexiones en torno al desarrollo filosófico en que plasmó Agustín esta necesidad vital de su alma. San Agustín buceó muy a lo hondo en los problemas filosóficos de todos los tiempos justamente para esclarecer ese horizonte que llenaba su vida: DIOS y el ALMA.

Los antiguos comenzaron a filosofar contemblando la naturaleza, es decir, mirando hacia afuera. Un buen día llegaron a sorpren-

1. Serm. XLIII, 7,9. 
derse a si mismos mirando; y, muy admirados, vinieron a caer en la cuenta de que ellos mismos valían más que el mundo que contemplaban. Sin embargo, nunca se libraron del todo de la fascinación del mundo sensible. San Agustín había vivido con los filósofos antiguos, acompañándolos, como él dice, "per largos circuitus errorum". De ellos le quedó un ardiente amor a la verdad y una desolada desesperación de poder conseguirla, ya que en ninguna parte la veía con signos inequívocos.

Cuando, al fin, la Verdad se le hizo encontradiza envuelta en los cendales de la fe, Agustín comenzó a ver claro. "Crede ut intelligas". ¿Es que tenemos que pensar que el razonamiento filosófico es de suyo tan débil que no pueda sostenerse si no es apoyado en la fe teológica? Más bien diría yo, que la debilidad está en el hombre y no tanto en el razonamiento filosófico. Parece, en efecto, un hecho de experiencia que cuando el hembre no tiene la seguridad de Dios, es incapaz del sentimiento de certeza. Pero, ¿indica esto deficiencia gnoso jlógica, o tal vez cierta debilidad ontológica en el hombre? Sin duda San Agustín antes de su conversión meditó largamente con Platón y Sócrates en las excelencias de la inteligencia humana; pero tan percurbada e insegura, ¿cómo podria considerar anclada en ella la "Ver"ᄀ.d". aue de suyo o tiene que ser inconmovible, o no "es" en modo a.lžuno? Lo cierto es que Agustín, al ser iluminado por la fe, cambió ac perspectiva. Comprendió claramente que la firmeza del hombre no podía estar del lado de la materia, y volvió la espalda a las cosas sensibles, y dirigió su mirada hacia dentro de sí mismo. $Y$ en las profundidades de su propio espíritu, o más allá tal vez, comenzaron a brillar para él los fulgores inequívocos de la "Verdad".

Hablamos de la verdad filosófica de la razón humana en cuanto es capaz de aclarar los problemas sobre la inmortalidad del alma y la existencia de Dios. La luz que se desprende del análisis atento del hecho maravilloso que constituye el conocimiento humano, es la que toma Agustín por guía, y le hace saber que su vida no es efímera, sino inmortal, e ilustra sus itinerarios hacia Dios. En la naturaleza del alma en cuanto racional encuentra los elementos necesarios para resolver su problema tan perfectamente como le es posible a la razón humana.

\section{LA INMORTALIDAD DEL ALMA}

Dios se muestra a la mente humana a la manera que se muestra el sol a los ojos corporales; no precisamente en una mirada directa, lo que bien pudiera enceguecernos, sino en la visión de la luz que esparce en los objetos que están sobre la tierra. Los principios y axiomas de las ciencias reciben de Dios la luz de su certeza al modo que los objetos materiales son iluminados por el sol. 
"Los principios inconmoviblemente ciertos de las ciencias y de las artes humanas, son a la manera de las cosas que ilumina el sol para que puedan ser vistas...; Dios es justamente el Sol que los ilustra" 2 .

Ahora bien, ¿dónde están los ojos capaces de ver la luz de este Sol y cuál es su linaje? Esos ojos son los de nuestra alma racional.

"Yo, la razón, soy para la mente espiritual lo que la mirada para los ojos materiales" 3 .

En el alma pueden ccnsiderarse tres cosas: los ojos, la mirada y la visión. Los ojos son la mente, la mirada es la razón y la visión no es otra cosa que la mirada perfeccionada, o sea, la que ha conseguido su intento.

\footnotetext{
"La llamamos virtud; puesto que virtud no es otra cosa que "razón recta", o "razón perfecta" ".
} visio Dei".

Esta "virtud" que informa a la "perfecta ratio" debe ser entendida en un doble sentido : físico y moral. La "ratio" pide fundamentalmente una entidad de algún modo existente y capaz de ver, plasmada en una naturaleza física, que si está afectada por adherencias viciosas, sufrirá una disminución en su potencia visiva, o tal vez quedará enteramente ciega. Será entonces necesario disolver los vicios y purificarla con la virtud, para que recupere plenamente su misińn. Mientras no se consiga esa pureza totalmente, no habrá "perfecta ratio", ni podrá seguirse "ipsa visio Dei".

"Son oios de la razón sänos una mente pứificada de toda inmundicia corpórea" 5 .

En los primeros días de su conversión posiblemente acarició San Agustín la idea de que aun en esta vida mortal, aunque rara vez y muy dificultosamente, podría realizarse tal purificación en el alma, que la hiciera capaz de ver directamente a Dios. (Vid. Sol. 1.14.24). Pero no debió durarle mucho tiempo este pensamiento, que él mismo corrige expresamente en sus Retractaciones. Mientras estamos en esta vida, nuestra alma se verá siempre como opacada en su unión con los setidos corporales, y esto, no por vicio, sino por naturaleza; y estando así las cosas es imposible que vea a Dios directamente la mente humana.

2. Disciplinarum quaeque certissima, talia sunt qualia illa quae sole illustrantur ut videri possint... Deus autem est ipse qui illustrat". (Sol. 1, 6, 12, PL. 32, 875).

3. "Ego autem ratio, ita sum in mentibus, ut in oculis est adspectus". 1b. 1, 6, 12, PL. 32

4. "Virtus vocatur: est enim virtus vel recta vel perfecta ratio". (Ib. I, 6, 13, PL. 32, 876).

5. Oculi sani mens ab omni labe corporis pura. (Ib. I, 6, 12, PL. 32, 875). 
Pero si no puede ver al sol de hito en hito, verá al menos su luz iluminando las verdades eternas. Aquí está el arranque de la vigorosa doctrina agustiniana de la iluminación, y también el origen de sus vacilaciones y dificultades.

"La visión misma es el acto intelectual que reside en el alma, y está formado con algo que es propio del inteligente, y algo propio de lo que es entendido. Si alguno de los dos falta, no es posible la visión" 6 .

La acción o visión intelectual no puede darse en nosotros sine mediante la conjunción de nuestra mente con aquello que es inteligido. $\mathrm{Y}$ ¿qué es eso que puede ser inteligido?

"Inteligible es Dios e inteligibles son aquellos principios (a que antes nos referiamos) de las artes y ciencias; sin embargo, mucho se diferencian entre si" ?

El inteligible por excelencia es Dios; pero también son inteligibles los axiomas y principios generales de las ciencias. ¿Son dos clases de inteligibles enteramente independientes entre sí? De ninguna manera. Eviaencemente son distintos; pero es imposible que estén totalmente desunidos e independientes. También la tierra visible es distinta de la luz; pero si la luz no la ilumina, la tierra no puede verse.

"Por lo tanto debemos creer que de ningún modo podriamos entender los principios que se enseñan en las ciencias, y que cualquiera que los entiende concede sin vacilar que son del todo verdaderos, si no estuvieran iluminados por un Sol, no como el ordinario, sino propio suyo, y acomodado a su naturaleza" 8 .

No hay más que un Sol capaz de iluminar las inteligencias: Dios. Y así como en el sol material que brilla sobre la tierra para que podamos verla, podemos considerar tres cosas: que es, que resplandece, que ilumina;

"Del mismo modo, en aquel Dios, tan secreto para nosotros, hay tres respectos: que es, que es inteligible y que ham ce inteligible todo lo demás" ".

Cuando, pues, la mente humana percibe verdades que claramente ve que son eternas e inconmovibles, debe colegir que la luz en que las ve procede de Dios, y que ellas mismas son un reflejo de esa luz divina, merced a la cual son verdad inconmutable.

6. Ipsa autem visio, intellectus est ille qui in anima est, qui conficitur ex intelligente et eo quod intelliaitur... Quorum detracto quolibet, videri nihil potest. (Ib. I, 6, 13, PL. 32, 876).

7. Intelligibilis Deus est, intelligibilia etiam illa disciplinarum spectamina, tamen plurimum differunt. (Ib. I, 8, 15, PL. 32, 877).

8. Ergo et illa quae in disciplinis traduntur, quae quisquis intelligit, verissima esse nulla dubitatione concedit, credendum est ea non posse intelligi nisi ab alio quasi suo sole illustrentur. (Ib. 1, 8, 15, PL. 32, 877)

9. Ita in illo secretissimo Deo tria quaedam sunt: quod est, quod intelligitur, et quod caetera facit intelligi. (Ib. I, 8, 15, PL. 32, 877). 
Tenemos por tanto conciencia de que nuestra mente es capaz de concebir verdades de suyo inconmovibles y eternas, y las ve a la luz de un sol que está muy por encima de las mismas. Este hecho ilumina vivamente los dos problemas fundamentales que preocupan a San Agustín. El alma capaz de contener dentro de sí misma verdades eternas, ¿no tendrá que ser inmortal? San Agustín formula el argumento de esta manera:

"Si permanece siempre to que hay en el sujeto, es necesario que también el sujeto mismo permanezca siempre. Pero toda disciplina o arte está en el alma como sujeto. Luego es preciso que el alma permanezca siempre, si los principios del arte son permanentes. Mas los principios del arte son verdad, y la verdad permanece siempre. El alma, por tanto, no puede perecer" 10 .

Los principios de las ciencias son verdad perenne y están en el alma como en su sujeto; luego el alma que los contiene debe ser también inmortal. Para que el argumento resulte firme necesita importantes aclaraciones. En primer lugar, ¿qué pensaremos de las almas rudas que nunca consiguieron ciencia alguna? Además, ¿cómo está la verdad en el alma? ¿Está, en efecto, como un accidente en el sujeto? ¿Es algo que pertenece a la razón humana como por derecho de naturaleza, o es algo que está lejos y sólo a lo lejos puede contemplar la mente? Los libros de los Soliloquios llegan a su fin sin dejar aclarada enteramente la cuestión. En sus Retractaciones nos dice San Agustín que en el libro segundo de los Soliloquios habla largamente de la cuestión sin llegar a una conclusión definitiva: "De inmortalitate animae diu res agitur et non peragitur".

Para resolver la dificultad que se presenta a propósito de las almas ignorantes, que al parecer, nunca llegan a poseer verdad alguna que merezca el nombre de eterna, se inclina a aprobar la doctrina platónica de la reminiscencia; pero la rechaza y reprueba terminantemente en sus Retractaciones, y termina con estas importantes palabras:

"Es mucho más creíble que responden con verdad sobre algunos principios científicos los que nunca los habian aprendido antes, cuando son interrogados con destreza, porque están iluminados en la medida de su capacidad por la luz de la razón eterna, en la que ven esas verdades inconmutables; y no porque las conocieron en otro tiempo y las tenían olvidadas, como piensan Platón y otros" ${ }^{11}$.

\footnotetext{
10. Omne quod in subjecto est, si semper manet, ipsum etiam subjectum maneat semper necesse est. At omnis in subjecto est animo disciplina. Necesse est igitur semper ut animus maneat si semper manet disciplina. Est autem disciplina veritas, et semper veritas manet. Semper igitur animus manet. (Ib. II, 13, 24, PL. 32, 896-897).

11. Credibilius est enim, propterea vera respondere de quibusdam disciplinis, etiam imperitos earum, quando bene interrogantur, quia praesens est eis, quantum id capere possunt, lumen rationis aeternae, ubi haec incommutabilia vera conspiciunt; non quia ea noverant aliquando et obliti sunt, quod Platoni vel talibus visum est. (Retract. 1, 4, PL. 32, 590).
} 
San Agustín cierra el segundo libro de los Soliloquios con el propósito de añadir un tercero para terminar la cuestión planteada sobre la inmortalidad del alma. Con este fin redactó el opúsculo "De Inmortalitate Animae"; pero, como él explica en sus Retractaciones, este opúsculo no pasó de ser un memorandum, "quasi commonitorium esse volueram" con miras a la conclusión de los Soliloquios. Con lo que vemos que las fórmulas estampadas en él no son consideradas como definitivas por Agustín. Sin embargo, hay en él ideas muy dignas de ser tenidas en cuenta. Insiste en él en la idea fundamental:

"Es cosa manifiesta que el alma humana es inmortal, y que están escondidas en su interior todas las "razones verdaderas"; aun cuando parezca en su ignorancia u olvido que, o que nunca las tuvo, o que las ha perdido" 12 .

Es digna de especial atención la idea de que "Omnes verae rationes" están en el alma, aunque parezca que las ignora totalmente. En los libros "De Trinitate" insistirá en esta doctrina hasta perfeccionarla y concretarla en la "memoria sui", como expresión de la mente humana en su escueta naturaleza. Más adelante veremos cómo no da asidero alguno para las llamadàs "ideas innatas".

A fin de que aparezca claramente la secuencia "inmortalis ratio, inmortalis anima", hay que definir lo que es "razón", o por lo menos circunscribir íntegramente sus posibles modos en función con sus relaciones con el alma.

"Debemos procurar con todas nuestras fuerzas que aparezca claro qué es la razón, y determinar los sentidos en que puede definirse, a fin de que conste de la inmortalidad del alma en conformidad con todos y cada uno de ellos" ${ }^{13}$.

¿Qué es la razón? ¿Es por ventura la mirada del alma cuando intuye la verdad directamente? "Aut adspectus animi, quo, per se ipsum, non per corpus, verum intuetur".

¿Es tal vez la intuición misma de la verdad? "Aut ipsa veri contemplatio". ¿O será la verdad misma contemplada? "Aut ipsum verum quod contemplatur".

Si la razón es la mirada del alma, los ojos del espíritu, evidentemente éstos están en ella indisolublemente. Si la razón es la visión misma racional, es cierto también que tal visión no puede darse sin el alma. En torno a la tercera hipótesis se "debate una gran cuestión". La verdad que ve el alma y ve que es eterna, ¿puede subsistir por sí misma sin estar en ninguna alma?

"Acerca de lo tercero se debate una gran cuestión, a sa-

12. Manifestum est, inmortalem esse animum humanum, et omnes veras rationes in secretis ejus esse, quamvis eas, sive ignoratione sive oblivione, aut non habere aut amisisse videatur. (De Inmort. Animae, 4, 6, PL. 32, 1024).

13. Incumbendum omnibus viribus..., ut ratio quid sit, et quoties definiri possit sciatur, ut secundum omnes modos, et de animae inmortalitate constet. (Ib. 6, 10, PL. 32, 1025-1026). 
ber: si aquella verdad que ve el alma sin el auxilio de los sentidos, exista por sí misma y no por el alma, o si puede subsistir fuera del alma" 14.

Es de advertir que San Agustín habla aquí de la "razón", no como facultad del alma racional, sino como la razón de ser de la verdad universal. En este sentido, aun cuando desconozcamos la solución definitiva acerca de sus relaciones con el alma, es seguro que, en todo caso, no podría el alma contemplar la verdad inconmutable si no se uniera de alguna manera con ella.

"Sea cualquiera el modo de existir la verdad, no podría contemplarla el alma por sí misma, sino mediante alguna clase de unión con ella" Ib.

Por otra parte, es evidente que las cosas que entendemos no las vemos como colocadas en algún lugar distinto de nuestra propia alma.

"No se ve lo entendido como puesto en lugar distinto del que ocupa el alma misma que entiende" Ib.

San Agustín hace resurgir con la varita de su genio admirables resplandores a un lado y otro de la ruta que sigue en busca de la prosapia del alma y de los títulos que abonan su inmortalidad. Examina la más importante de sus operaciones, que brota desde el fondo más íntimo de su vida y de su ser: la intelección de la verdad; no sólo de verdades pasajeras, sino de la "verdad" que ella siente con perfecta certeza que es permanente y eterna; por ejemplo la verdad de los principios matemáticos. Ve que el alma como entidad viviente, es lugar adecuado en que reposa esa perenne verdad, en modo alguno suieta al fluir del tiemno, y ella la contempla dentro de sí misma. ¿No será esto indicio cierto de que la vida del alma en que se asienta la verdad inconmutable es también inmortal?

Evidentemente San Agustín se siente arrastrado por estos fulgores filosóficos hacia donde le llevaban las más profundas aspiraciones de su alma, y adonde ya había llegado conducido por la fe. Pero su absoluta honradez científica no le permite atribuir una certeza completa a la razón filosófica discutida. Y es que entre la verdad gnoseológica humana y su verdad ontológica hay una gran diferencia. No es lo mismo el ser que el conocer. Indudablemente hay relaciones íntimas entre ambos, ¿pero quién será capaz de esclarecerlas debidamente?

14. Ratio est... aut adspectus animi, quo per se ipsum, non per corpus, verum intuetur; aut ipsa veri contemplatio; non per corpus; aut ipsum verum quod contemplatur... De tertio magna quaestio est, utrum verum illud quod sine instrumento corporis animus intuetur, sit per se ipsum, et non sit in animo, aut possit esse sine animo. Quoquolibet modo autem se habeat, non id posset animus contemplari animus per se ipsum, nisi alioua conjuctione cum eo... Ea vero quae intelliauntur non quasi alibi posita intelliguntur quam ipse qui intelligit animus, simul enim etiam intelliguntur non contineri loco. (Ib. 6, 10, PL. 32, 1026). 
"La conjunción del alma que intuye con su verdad intuida, puede ser considerada de tres modos: 1.॰ de manera que el alma sea el sujeto, y su verdad puesta en el sujeto. $2 .^{\circ} \mathrm{O}$ al contrario, que el sujeto sea la verdad, y el alma como estando en el sujeto. 3. Que ambos a dos, alma y verdad, sean substancias" 15.

Naturalmente San Agustín no se inclina dialécticamente hacia ninguna de estas tres proposiciones. Le basta que la totalidad del asunto no rebase los límites acotados entre las tres. Pero se ve claro en ellos la dicotomía "fisis - noesis", que hace muy difícil un enfoque nitido de la cuestión. Esta oposición se hace particularmente agresiva en el tercer caso. "Remanet omnis pugna de tertio". Aun en este supuesto, el más difícil para la argumentación cue se persigue, siemore sería cierto que el alma cuando raciocina está unida a la "razón" y vive en ella. Y entonces, ¿quién podrá separarlas?

\begin{abstract}
"Es evidente aue al menos durante el tiempo en que el alma no está separada de la razón, sino adherida a ella, necesariamente persevera en su ser y vive. Y entonces, ¿qué fuerza habrá capaz de separarlas?" ${ }^{16}$.
\end{abstract}

Pero esto no es suficiente para que San Agustín diera por definitivamente resuelta la cuestión. El libro "De Inmortalitate Animae" no pasó de ser un "memorandum".

\title{
LA PRUEBA DE LA EXISTENCIA DE DIOS.
}

Para probar la existencia de Dios, San Agustín parte de los mismos presupuestos que indican la inmortalidad del alma; pero esta vez el terreno se muestra más firme. Nosotros experimentamos en nuestra conciencia la existencia de verdades enteramente independientes del tiempo. Es necesario, por tanto, o que ellas subsistan por sí mismas independientes del tiempo, o que tengan una sede aue esté sobre todos los tiempos. Ahora bien, sabemos que nuestra alma no ha existido siempre; aue su percepción de la verdad es variable, aun cuando la verdad misma de suyo no cambia; luego el asiento primero de la verdad no puede ser nuestra alma. San Agustín dedica casi todo el libro segundo de "De libero Arbitrio" al análisis de la prueba de la existencia de Dios fundamentada en este esquema. Comienza definiendo nuestra razón o inteligencia como algo que sobresale, a manera de cabeza $u$ ojos del alma; siendo de notar que así como en los Soliloquios gusta de cargar el acento al hablar de la

\footnotetext{
15. Ista conjunctio intuentis animi et eịus veri auod intuetur, aut ita est ut subiectım sit animus, verum autem illud in subjecto; aut contra: subjectum verum, et in subjecto animus; aut utrumque substantia (lb. 6,11, PL. 32, 1026).

16. Sed manifestum est quandiu animus a ratione non separatur, einue coharet, necessario eum manere et vivere. Separari autem, qua tandem vi potest. (Ib. 6, 11, PL. 32, 1026).
} 
"ratio" sobre la "verdad razonable", ahora prefiere cargarle sobre la "facultad raciocinante".

(Tenemos además) algo que es a modo de cabeza u ojos de nuestra alma o lo que pueda decirse con más propiedad de la razón o inteligencia" 17 .

$\mathrm{E}$ inmediatamente anota su versatilidad:

"Pero la razón misma a veces se afana por conseguir la verdad, y otras veces no... Lo cual demuestra claramente su mutabilidad" ${ }^{18}$.

En seguida plantea el argumento:

"Y si (nuestra razón) sin el auxilio de instrumento alguno corporal, sino por si misma, ve algo que es eterno e inconmutable, y al mismo tiempo se percata de que ella misma queda muy por debajo, debe confesar que aquello es su Dios" 19.

Para desenvolverlo convenientemente a fin de que aparezca clara la consecuencia, analiza cuidadosamente los elementos de las premisas: el alma racional y la verdad. Por lo pronto es cosa cierta que cada uno de nosotros tiene su propia mente racional. Examina la cuestión en el cap. VII, 15, donde concluye:

"Está claro también que cada uno de nosotros tiene su propia mente racional" 20 .

Pero en contraste con la multiplicidad de mentes capaces de percibir la verdad, hay algo que, siendo único, se da a ver en común a muchos. Pregunta Agustín a Evodio, su colocutor en "De Libero Arbitrio":

Ag. "Podrías mencionar algo aue todos cuantos son capaces de raciocinar vean en común, cada cual con su propia mente y razón;... y... que permanezca integro e incorruptible de suyo, tanto si aquéllos lo ven, como si no lo ven? Ev. No sólo una, sino muchas cosas veo de este género; entre las cuales baste traer a cuento una, a saber: Ia razón $\mathrm{y}$ verdad de los números está siempre a disposición de todos cuantos raciocinan, a fin de que cuaquier contador pueda apresarla con su razón e inteligencia; y unos lo consiguen fácilmente, y otros con gran dificultad" 21 .

17. Quiddam quasi animae nostrae caput aut oculum, aut ai quid congruentius de ratione atque intelligentia dici potest, (De Lib. Arb. II, 6, 13, PL. 32, 1248).

18. Ipsa ratio cum modo ad verum pervenire nititur, modo non nititur... mutabilis esse prorsus convincitur. (Ib. II, 6, 14, PL. 32, 1248). (

19. Quae si nullo addito corporis instrumento..., sed per se ipsam cernit Aeternum aliquid et incommutabile, simul et seipsam inferiorem, et illum opportet Deum suum esse fateatur. Ev. Hunc plane fatebor Deum, quo nihil superius esse constiterit. Aug. Bene habet: nam mihi satis erit ostendere esse aliquid hujusmodi, quod aut fateberis Deum esse, aut si aliquid supra est eum ipsum Deum esse concedis. (Ib. II, 6, 14, PL. 32, 1248).

20. Manifestım est enim rationales mentes singulos quosque nostrum singulas habere (Ib. II, 7, 15, PL. 32, 1249).

21. Aug. Utrum inveniatur aliauid quod omnes ratiocinantes sua quisaue ratione ataue mente communiter videant? Ev. Immo multa esse video; e quibus unum commemorari satis est, quod ratio et veritas numeri omnibus ratiocinantibus praesto est; ut omnis computator sua quisque ratione et intelligentia conetur apprehendere; et alius id facilius, alius dificilius possit. (Ib. II, 8, 20, PL. 32, 1251). 
Bien: la razón y verdad matemática vista por los hombres, no consiste en la razón humana; es algo que está fuera de ella. Pero ¿dónde? ¿No estará, sea ella lo que fuere o como fuere, esparcida en los objetos sensibles, de donde los recoge nuestra razón?

"Y si alguien te objetare que nosotros no percibimos Ios números en algo que corresponda a su propia naturaleza, sino en las cosas mismas que tocan nuestros sentidos corporales, recibiéndolos a la manera de las imágenes de los objetos visibles que se imprimen en nuestra alma, ¿qué responderías? ¿O quizá piensas tú también que ello es así? 22 .

Evodio responde vivamente que de ningún modo. Pueden verse con los sentidos los números que se pintan en la pizarra; pero de ninguna manera ocurre lo mismo con sus razones y proporciones. En suma:

"De todas las cosas que percibo con los sentidos del cuerpo... ionoro hasta cuándo han de durar; nero estoy bien seguro de que siete más tres son diez, no sólo ahora, sino por siempre jamas" 23 .

San Agustín dedica los números 21, 22 y 23 del cap. VIII a la refutación de esta idea, tan del gusto de los modernos empiristas, $\mathrm{y}$ termina con estas palabras:

"Eso que vemos mantenerse inmóvil, firme e incorruptible por sobre toda la serie de los números, ¿en qué parte lo vemos? Nadie puede alcanzar con ningún sentido todos los números, puesto que son incontables. ¿En qué conocemos entonces que se extiende por todos ellos, o con qué fantasía, o mediante qué fenómeno..., si no es por verlos en cierta luz interior, totalmente ignorada por los sentidos?" ${ }^{24}$.

Es imposible que las verdades matemáticas, que con certeza plena vemos "inconmutables, firmes e incorruptibles" tengan su fundamento en los cuerpos visibles que experimentamos constantemente variables. Tienen que fundamentarse en algo espiritual y eterno, que es a la vez luz de nuestras mentes. Queda, pues, en claro que:

"La razón y verdad de los números no pertenece a los sentidos, permanece incontrastable y pura, y está a disposición comunitaria para que puedan verla todos los que tengan uso de razón" 25 .

22. Si tibi aliquis diceret numeros istos, non ex aliqua sua natura sed ex his rebus quas sensu corporis adtingimus, impressas esse animo nostro quasi quasdam imagines quorumcumque visibilium, quid responderes? An tu quoque id putas? (Ib. II, 8, 21, PL. 32, 1251-1252).

23. Quidquid sensu corporis tango... quandiu futura sint nescio: septem autem et tria decem sunt; et non solum nunc sed etiam semper. (Ib. II, 8, 21, PL. 32, 1252).

24. Hoc ergo quod per omnes numeros esse immobile, firmum, incorruptumque conspicimus, unde conspicimus? Non enim ullus ullo sensu corporis omnes numeros adtingit, innumerabiles enim sunt; unde ergo novimus per omnes hoc esse, aut qua phantasia vel phantasmate..., nisi in luce interiore conspicitur, quam corporalis sensus ianorat? (Ib. II, 8, 23, PL, 32, 1253).

25. Rationem veritatemque numerorum, et ad sensus corporis non pertinere, et invertibilem sinceramaue consistere, et omnibus ratiocinantibus ad videndum esse communem. (16. 11, 8, 24, PL. 32, 1253). 
Por tanto, la verdad matemática no se multiplica esparcida en los cuerpos sensibles, ni tampoco en los números materiales, ni en los diversos teoremas de la Aritmética o Geometría; sino que abarca con simplicidad a toda la ciencia de los números y proporciones.

Aparte de la verdad de los números, que brilla tan claramente en la inteligencia, tenemos las verdades morales, en que se combinan inteligencia $\mathrm{y}$ voluntad para investigar el bien $\mathrm{y}$ apetecerle. San Agustín gusta de dar el nombre de sabiduría a este nuevo conjunto de verdades.

"¿Te parece que la sabiduría es otra cosa que la verdad en que se ve y posee el sumo bien?" ${ }^{26}$.

Naturalmente aplica a la sabiduría las mismas consideraciones que a la ciencia de los números:

"Quiero que me digas si te parece que la sabiduría es también común para todos los que son capaces de razonar, lo mismo que la razón y verdad del número?" ${ }^{27}$.

Así como la ciencia general de todas las relaciones numéricas debe ser considerada como algo unitario que se ofrece a la contemplación de todas las mentes capaces de poseerla, sin menoscabo ni variación alguna de su parte, del mismo modo el conocimiento $\mathrm{y}$ apetencia de las verdades morales, que se despliegan en variedad solamente en su referencia a las criaturas, proceden y se refunden de nuevo en una sola sabiduría.

“¿Qué te parece? Esa sabiduria, en que ya estamos de acuerdo que existe, o ese deseo que tienen todos los hombres de ser sabios y dichosos ¿en dónde los vemos?... Y la verdad única que vemos ambos cada cual con nuestra propia mente, ¿no es común para los dos?" 28.

Lo que de suyo es uno, se muestra en su totalidad a muchas mentes a la vez, lo cual anula toda exclusión y hace saltar definitivamente todo cerco de propiedad individual.

"Podrá alguien decir que es propia suya esa verdad, siendo así que se muestra inconmutablemente a la contemplación de cuantos sean capaces de contemplarla?" ${ }^{29}$.

San Agustín se detiene en el examen de diversas cuestiones que tocan a lo moral e insiste en la unificación de todas ellas en torno de la sabiduria, y concluye:

\footnotetext{
26. Num alia putas esse sapientiam nisl veritatem in qua cernitur et tenetur summum bonum? (Ib. II, 9, 26, PL. 32, 1254).

27. Volo jam dicas mihi utrum etiam sapientiam, sicut numeri rationen ataue veritatem; omnibus ratiocinantibus communem se praebere arbitreris? (Ib. II, 9, 27, PL. 32, 1255).

28. Quid? hoc quod tenemus vel esse sapientiam, vel sapientes et beatos esse omnes homines velle, ubi videmus?... Quod ergo unum verum videmus ambo singulis mentibus, nonne utrique nostrum commune est? (Ib. II, 10, 28, PL. 32, 1256).

29. Hoc ergo verum potest quisque suum proprium dicere, cum incommutabiliter contemplandum adsit omnibus qui hoc contemplandum valent? (Ib.).
} 
"Me abstendré de analizar más cosas de este género... Está, pues, claro que todo eso que hemos llamado reglas y luz de las virtudes, pertenece a la sabiduria" 30.

Por consiguiente, lo dicho a propósito de la ciencia de los números, se cumple asimismo en la sabiduria de las reglas acerca del bien.

"Tan verdaderas e inconmutables como son las reglas de los números..., son verdaderas e inconmutables las reglas de la sabiduía...; y concedes que todas ellas se ofrecen en común a la contemplación de todcs los que son capaces de contemplarlas" 31

Pero surge la cuestión de si la ciencia de los números y la sabiduría sobre lo bueno y lo malo no representarán dos regiones tan diferentes, que resulten irreductibles entre sí ya que, como se puede observar en los pareceres de la gente, la habilidad de los contadores es despreciable frente a la sabiduría de los filósofos.

Ev. "Mas daría mucho por saber si ambas cosas, o sea sabiduría y número se contienen en algún género..., o si la una depende del otro... Que la sabiduría dependa del número, o consista en el númeio, no me atrevería a creerlo...; pues conozco muchos contadores...; pero sabios, muy pocos...

Ag. Dices algo que también a mí me tiene en suspenso... Mucho me admira, en efecto, que participando las dos de la misma secretísima y ciertísima verdad..., el vulgo desprecia los números y tiene a la sabiduría en gran estima" 32 .

Mas el parecer del vulgo no tiene por qué ser decisivo en este pleito. El resplandor que emite como propio una lámpara es sin comparación más precioso que el despedido de prestado por el oro. Pero se aprecia más el oro, porque "hasta un mendigo puede encender su lámpara". Así el vulgo ve que no es tan difícil contar hábilmente; pero son muy pocos los que pueden alcanzar la sabiduría. Sin embargo los doctos, los que saben apreciar las cosas en lo que verdaderamente valen, no opinan como el vulgo.

"Los doctos y estudiosos, cuanto más libres están de la contaminación de lo terreno, tanto mejor ven los números y la sabiduría en la misma verdad, y estiman ambas cosas igualmente" 33 .

Pero ya sea que nuestra ciencia de los números y nuestra sabiduría acerca de lo que es bueno estén mutuamente subordinadas, o

\footnotetext{
30. Jam hujusmodi plurima non quaeram... Manifestum est ignitur omnes has quas regulas diximus et lumina virtutum, ad sapientiam pertinere. (Ib. II, 10, 29, PL. 32, 1256).

31. Quam ergo verae atque incommutabiles sunt regulae numerorum..., tam sunt verae atque inconmutabiles regulae sapientiae... easque omnibus qui haec intueri valent, communes ad contemp!andum addesse concedis. (Ib. II, 10, 29, PL. 32, 1257).

32. Ser pervellem scire utrum aliquo genere contineantur haec duo, saplentia scillcet of numerus...; an alterum exsistat ab altero... Sapientiam exsistere a numero aut consistere in numero, non ausim dicere... Multos novi numeratores..., sapientes perpaucos ... Rem dicis quam ego quoque mirari soleo... Multum miror cum haec duo sint in secretissima certissimaque veritate..., quare numerus vilis sit muititudini... et cara sapientia. (Ib. II, 11, 30, PL. 32, 1257).

33. Docti autem et studiosi, quanto remotiores sunt a labe terrena, tanto magis et numerum et sapientiam in ipsa veritate contuentur, et utrumque carum habent. (Ib. II, 11, 31, PL. 32, 1258).
} 
más bien deban incluirse juntas bajo un mismo nombre común para entrambas, lo cierto y decisivo para nuestro propósito es que todo cuanto en ellas vemos, lo vemos en la verdad inconmutable, y por tanto, única.

"Fijate sólo en esto, que es suficiente para la cuestión que traemos entre manos..., que aunque no conste si el número está en la sabiduria o sale de ella, o si es la sabiduria la que procede del número..., o son los dos la misma cosa, siempre resulta claro y manifiesto que ambos a dos son verdad y verdad inconmutable" 34 .

Hay, pues, muchas mentes; pero es una sola la verdad aue se muestra en común a todas las mentes; que no es propiedad privada de ninguna, y que está por encima de todas ellas. Es menester examinar atentamente la deducción de la existencia de esa "verdad ún" ca" e independiente de nosotros, a partir de los datos de nuestra experiencia gnoseológica, siguiendo los pasos de San Agustín.

Nosotros tenemos conciencia de muchas verdades, que podemos clasificar incluso, por su mayor o menor importancia. Están, sea ello como fuere, dentro de nosotros y forman el caudal de nuestra ciencia, o si se prefiere, de nuestros conocimientos: son, pues, nuestros. Sin embargo, a poco que reflexionemos sobre todas y cada una de nuestras pequeñas o grandes verdades, hay y vemos en todas ellas algo que no nos pertenece. Es como una luz en alto gracias a la cual es visible todo cuanto vemos. Consideremos la más sencilla de las verdades matemáticas, por ejemplo: siete más tres son diez. Yo estoy considerando "ahora" esta proposición; tengo ante mi vista o en la imaginación pintados ese 7 , ese 3 y ese 10 , y comprendo la justa relación que hay entre ellos, y tal vez utilizo a voluntad todo eso. En este sentido el conocimiento de esa proposición es mío. Pero por encima de todo eso hay algo que no me pertenece, y es "la verdad" de que siete más tres son diez. Esta verdad no es mía. Para serlo, tendría que tener su origen en mi ser; bien en mi voluntad o en mi inteligencia o en cualquier otra cosa mía; y de tal manera, que si yo no quisiera que fuese eso verdad, o no lo entendiera en acto o yo no existiera, tampoco seria cierto que siete más tres son diez.

Los números que yo he dibujado, o que me imagino o pienso, las operaciones psicológicas o de cualquier clase que se realizan en mí en torno de tal proposición cuando me hago cargo de ella, sí son mias; pero su verdad, de ningún modo me pertenece ni depende de mí. Estoy bien seguro de que antes de que yo existiera, ya era verdad que siete más tres son diez, y lo será aunque yo deje de existir.

Además, la verdad que yo veo en esta proposición es la misma

34. Tantum illud adtende, quod et quaestioni quam suscepimus satis est... quia etsi clarum nobis esse non potest, utrum in sapientia vel ex sapientia numerus, aut ipsa sapientia ex numero.... Aut utrumque nomen unius rei possit ostendi, illud certissimum et manifestum est utrumque verum esse, et incommutabiliter verum. (Ib. II, 11, 32, PL. 32, 1258). 
que ve cualquier mente humana que la considere haciéndose cargo de ella; y es la misma siempre totalmente independiente del espacio y del tiempo, lo mismo que todas y cada una de las mentes humanas, que pueden verla, pero no juzgar de ella, porque está por encima de todas las mentes.

\begin{abstract}
"Cuando alguien afirma que las cosas eternas son mejores que las temporales, o que siete más tres son diez, no dice que así debería ser; sino sabiendo tan sólo que así es, se limita a alegrarse con su encuentro, y no trata de introducir correcciones como juez" ${ }^{35}$.
\end{abstract}

De modo semejante debemos discurrir sobre los diversos axiomas, reglas generales y leyes de la naturaleza que expresan verdades constantes. Todas esas cosas son diversas y múltiples en relación con nuestra facultad cognoscitiva. Más aún, podemos afirmar que, en su forma múltiple, sólo existen gnoseológicamente, es decir, en nuestra mente racional; pues ellas de por si, no tienen existencia física. Sin embargo, sobre todas ellas, independientemente de nosotros, brilla una luz de verdad que las hace verdaderas. Kant nos diría que su verdad es un "a priori" fundado en nuestra razón; pero San Agustín refutó a Kant por anticipado. El "a priori" en que se fundamentan todas las verdades generales, más aún, cualquier clase de verdad conocida por nosotros, tiene que estar muy por encima de las posibilidades de nuestra mente racional.

Para San Agustín es de gran importancia esta independencia de la verdad con respecto a la mente humana que la contempla; insiste mucho en ello, y para hacerlo comprender mejor, echa mano de ejemplos tomados de las cosas sensibles. Tú y yo vemos un mismo color y escuchamos un mismo sonido al mismo tiempo, y deducimos que tal color y tal sonido no son cosa exclusiva y propia de cada uno; sino algo, que siendo distinto de nosotros, se da en común para los dos. Pues

"Del mismo modo, aquella verdad que tú y yo vemos en común, cada cual con nuestra propia mente, de ninguna manera puede decirse que pertenece a la naturaleza de alguno de nosotros" ${ }^{36}$.

Pero justamente estas verdades sensibles a las que San Agustín da tan poca importancia y a las que acude sólamente como mero recurso pedagógico para el desarrollo de sus más altas ideas, son las únicas admitidas por los modernos empiristas; ya que sólo ellas pueden ser comprobadas por la experiencia. En consecuencia rechazan, sin examinarlo siquiera previamente, todo el proceso men-

35. Cum enim quis dixerit aeterna temporalibus esse potiora, aut septem et tria decem esse, non dicit ita esse debuisse, sed tantum ita esse cognoscens, non examinator corrigit, sed tantum laetatur inventor. (Ib. II, 12,34, PL. 32, 1259)

36. Sic ergo etiam illa quae ego et tu communiter propria quisque mente nequaquam dixeris ad mentem alicujus nostrum pertinere naturam. (Ib. II, 12, 33, PL. 32, 1259). 
tal agustiniano. Para ellos es inútil discutir sobre la posible existencia de cualquier entidad que no pueda ser experimentada por los sentidos. Se puede discutir sobre la realidad independiente de aquello que vemos en común allá lejos, y nos parece que, por ejemplo, es un "árbol", porque podemos hacer varias experiencias acerca de él con nuestros sentidos; y así ponernos de acuerdo "razonablemente". Mas eso que llamamos "la verdad" de las proposiciones científicas y morales, ¿cómo comprobaremos que, por decirlo así, tiene peso y substancia propia, o sea, una realidad que subsiste fuera de la subjetividad de nuestra mente? Desde luego, no por los sentidos, ni por ninguna experiencia empírica, que, al decir de los empiristas y kantianos, son los únicos modos oue pueden certificarnos de que eso que resolvemos en nuestra mente no es una mera quimera tan pronto como queremos proyectarlo fuera de nuestra propia subjetividad.

Y Kant nos instruiría amablemente para desengañarnos, asegurándonos que esa idea de verdad que sobrevuela como algo independiente por encima de todo lo que tenemos por verdadero, no es más que un producto subjetivo de nuestra razón, que ella elabora para tener un a modo de punto de referencia, del que se sirve para ordenar como es debido los datos oue le presentan los sentidos en desorden; pero que en modo alguno rebasa los dominios de la pura subjetividad. Es una forma "aprioristica" de nuestra facultad cognoscitiva meramente analítica; o sea, totalmente vacía de cualquier contenido experimental posible.

Este viene a ser el razonamiento de los que niegan hasta la posibilidad para nosotros los hombres de obtener una certeza razonable acerca de la existencia de algo que, aun cuando tenga subsistencia propia fuera de nosotros, sea totalmente inasequible a la experiencia empírica.

Para analizar este criterio debemos comenzar puntualizando que nuestras experiencias "reales", no son únicamente las empíricas, es decir, las que se fundamentan en la percepción de los sentidos. Como diría San Agustín, nuestros conocimientos "concretos" (llamémoslos asi, aunque por otra parte son generales) de los elementos y principios de las ciencias: siete más tres son diez; proporción de la circunferencia al diámetro; propiedades diversas de las proporciones aritméticas o geométricas, y en general, el conocimiento de cualquier verdad filosófica o moral, esos conocimientos que son claros o menos claros para nosotros; que aparecen en nuestra mente, o desaparecen sepultados en el olvido, son experiencias nuestras muy reales y concretas; que aunque a veces tengan su origen en alguna percepción sensible, evidentemente están muy por encima de toda posible experiencia empirica. $Y$ con todo, obtenemos con ellas certezas mucho más seguras y firmes oue las proporcionadas por los sentidos sobre la realidad de los cuerpos 
materiales. ¿Que todas estas experiencias internas nuestras son meramente subjetivas y no exhiben caracteres de realidad propia independiente? Pase por el momento. Pero debe quedar bien establecido que son experiencias nuestras reales, y no meramente ilusorias, en las cuales percibimos verdades que no son empíricas; pero sî́más ciertas y seguras para nosotros que cualquier verdad establecida por vía empírica. $\mathrm{Y}$ no se diga que tienen su origen en la experiencia empírica por cuanto nuestra razón se sirve de datos sensibles, por eiemnlo, líneas y figuras geométricas dibujadas en la arena, al establecer y comprobar sus verdades generales científcas; porque eso no anula el hecho de nuestras experiencias reales no empíricas. Es verdad que nuestra inteligencia trabaja en íntima unión con los sentidos; pero los elementos propios de su trabajo están decididamente más allá del dato escueto oue por ventura aportan los sentidos. Acerca de esto merece ser leído el cap. VIII del libro segundo de "De Libero Arbitrio".

Por otra parte, hay en estas relaciones de lo inteligible con lo sensible algo muy digno de no ser pasado por alto. Supongamos un concepto cualquiera nuestro. Sea el concepto de árbol. Es una entidad ideal que sólo existe en alguna mente mediante algún proceso psicológico concreto. Sin embargo, tiene un valor de aplicación trascendental. Hay muchos árboles concretos, independientes los unos de los otros en cuanto a su ser individual y diferentes de muchas maneras; a todos los cuales sin excepción les es aplicable $m$ i concepto de árbol.

Los empiristas afirman que los conceptos mentales son meras sinonsis de las semeianzas que en sus diversas experiencias perciben y nos presentan los sentidos; pero esto no es cierto. Los sentidos sólo perciben casos concretos aislados, y en la sinopsis de unos cuantos casos, no pueden entrar todos los árboles existentes y posibles, como entran en el concepto. Además, los sentidos son incanaces de establecer semeianzas, las que están muy por encima de todo nroducto emnírico. Por otra parte, sea cual fuere el mecanismo por el aue nuestra mente se apercibe de las semeianzas recogidas en el concepto, es lo cierto que, siendo tantos los árboles concretos rue gozan cada cual de una entidad propia incomunicable. tienen todos, no obstante, algo comunitario, que no denende de mí ni de mi concento, ignorado enteramente de los sentidos. Algo a aue anunta mi concepto, oue flota, por decirlo así, sobre el coniunto de todos los árboles, $y$ que ha menester de una explicación ontológica y no meramente lógica; puesto aue radica en el ser de los mismos, y nn en mi concepto, que también es concreto en cuanto acción nsicológica en la que se muestra un valor lógico trascendental. Sería falseante este valor si no hubiera fuera de mí algo oue pertenece en común a todos y cada uno de los árboles existentes y posibles, que es para mí un auténtico problema ontológico del que nada me 
dicen los sentidos. Algo que no es mío ni es propiedad exclusiva de cada árbol, sino comunitario entre todos. No existiría el concepto si no estuviera en alguna mente capaz de formarlo apercibiéndose de lo que él contiene; y no sería concepto verdadero, si su contenido no perteneciese a todos los árboles. Esa comunidad ontológica junto con la mente capaz de apercibirla, es lo que hace posible la formación de los conceptos, y no una mera percepción sensible sucesiva de objetos.

De semejante manera podemos discurrir acerca de la idea de ser en general, trascendental que se aplica a todas cuantas entidades puedan cntrar de algún modo en relación con nuestro conocimiento del ser. No sería posible el concepto general de ser, ni su aplicación verdadera a todos los entes, si no fuera cierto que todos ellos participan comunitariamente de alguna manera del mismo y único ser.

Tenemos, pues, en nuestras experiencias internas no empíricas, pero si concretas a su modo y reales, algo que no está al alcance de los sentidos; ni tampoco debe ser declarado como meramente subjetivo o quimérico. Es esta experiencia nuestra sumamente variada, $y$ en ella se comprenden todas las consideraciones que hace San Agustín sobre las verdades matemáticas, o filosóficas, o de cualquier género, que nosotros podemos adquirir más o menos perfectamente, con más o menos trabajo. Pero una vez adouiridas, contemplamos en ellas sin género de duda un valor inmutable no sujeto a espacios ni tiempos.

Nuestras experiencias gnoseológicas son muchas y de diverso valor; pero en todas ellas vemos y experimentamos, con un modo de experiencia muy distinto de la experiencia empírica, pero no menos real y eficaz, que hay algo que no radica en nosotros, ni depende de nosotros, que ilumina nuestras verdades particulares elevándolas a la categoria de verdad eterna.

"Por tanto, no podrás negar en modo alguno que hay una verdad inconmutable que envuelve todos nuestros axiomas inconmutablemente verdaderos; la cual no dirás que es tuya o mía, o de cualquier hombre; sino que es una luz de maravilloso modo secreta y pública a la vez, que está a disposición y se da en común a todos los que son capaces de percibir verdades eternas. Ahora bien, lo que se da en común a cuantos razonan y entienden, ¿habrá alguien que se atreva a decir que es cosa propia de la naturaleza de cualquiera de ellos?" ${ }^{37}$.

\footnotetext{
37. Quapropter nullo modo negaveris esse incommutabilem veritatem, haec omnia quae incommutabiliter vera sunt continentem, quam non possis dicere tuam vel meam, vel cujusquam hóminis, sed omnibus incommutabilia vera cernentibus, tanquam miris modis secretum et publihominis, sed omnibus incommutabilia vera cernentibus, tanquam miris modis secretum et publi-
cum lumen, praesto esse ac se praebere communiter: Omne autem quod communiter omnibus ratiocinantibus atque intelligentibus praesto est, ad ullius eorum proprie naturam pertinere quis dixerit? (Ib.)
} 
Esa verdad inconmutable que vemos sobre nuestras mentes, es sin duca superior y más excelente que nuestras mentes.

"Si esta verdad fuese igual que nuestras mentes, sería también mudable; ya que nuestras mentes a veces la ven mejor, y otras peor; con lo cual tienen que confesar que son mudables; siendo así cue ella, permaneciendo en si misma interra e incorruptible, alegra a los que la miran con su luz, y castiga con la ceguera a los que le vuelven la esoalda" ${ }^{38}$.

Es cierto que estas nuestras experiencias internas son gnoseológicas y subjetivas. No tienen un valor óntico de suyo, y por tanto, a primera vista, no parece oue pueda fundamentarse en ellas ninguna relación ontológica especial, aparte de los fenómenos psíqui$\cos$ que ocurren en nuestra propia alma. La dicotomía "fisis-noesis" es evidente también aquí. Pero al revés de lo que nos sucedía al tratar de la inmortalidad del alma, que tal diferencia tendía a frenar la fuerza de nuestro razonamiento, ahora, por el contrario, nos proporciona el punto de apoyo suficiente para efectuar legítimamente el salto desdo los hechos que comorobamos en nuestro propio campo gnoseológico, hasta algo que necesariamente debe subsistir más arriba de nuestra "psiouis". Las verdades eternas que vemos en el horizonte de nuestra "noesis" no prueban con suficiente claridad la vivencia eterna de nuestra "fisis". Comprobamos, en efecto, fácilmente que la base psíquica de nuestros conceptos lógicos es sumamente móvil, aun cuando la verdad lógica del concepto sea de suyo inconmutable. Estos hechos nos dejan confusos sobre la perennidad de nuestra "psiquis", el alma, y nos obliga a volver nuestra reflexión scobre esa maravilla que se nos descubre en la conciencia de nuestra percepción de verdades perennes. Siete más tres son diez, o la verdad oue informa cualduier secuencia matemática, nor eiemplo, la que desarrolla San Agustín en "De Lib. Arb." II, VIII 23. Dice en sustancia: en la secuencia de los números naturales, 2 que es el doble de 1, ocupa el primer lugar después del 1; 4, doble de dos, ocupa el segundo lugar después del 2; 6, doble de 3 ocupa el tercer lugar desvués del 3; y en general, el doble de cualouier número ocupa después de él el lugar ordinal indicado por dicho número. Es ésta una ley que se cumple infaliblemente en todos los incontables números que se puedan imaginar o no; que no se aboya en ningún número material, ni en ninguna fantasía o actividad de nuestra "psiquis". Sin embargo, la vemos en nuestro interior en toda su integridad y con absoluta certeza.

Ahora bien, esa nuestra visión de la verdad es noética, y la "noesis" no subsiste por sí misma: necesita un apoyo "físico" ade-

\footnotetext{
38. Si autem esset aequalis mentibus nostris haec veritas, mutabilis etiam ipsa esset. Mentes enim nostrae aliquando eam pl!s vidnnt. alinuando minu's. at a. hor. fotontur so esse mutabiles: cum illa in se manens integra et incorrupta et conversos laetificet lumine, et aversos puniat cecitate. (Ib. II, 12, 34, PL. 32, 1259).
} 
cuado. Nosotros la vemos mediante nuestros actos psíquicos vacilantes, unas veces mejor, otras peor, o no la vemos; pero cuando la vemos, estamos seguros, completamente seguros, de que ella, la verdad, no vacila jamás.

$Y$ sacamos la consecuencia: para que esa verdad perenne, que no tiene sustento adecuado ni en los entes que nos rodean, ni en nuestra propia "psiquis", pueda aparecer tan brillantemente en el horizonte de nuestra "noesis", es necesario que más arriba de lo que nosotros somos y de lo que vemos con nuestros sentidos, tenga su apoyo propio subsistente.

Aquí chocamos frente a frente con Kant; quien nos asegura que las verdades generales de nuestra razón son puramente subjetivas, meros instrumentos de trabajo con que la razón ordena las impresiones que le vienen desde los sentidos. No les corresponde absolutamente nada fuera de nuestra subjetividad. $\mathrm{Y}$ ¿cómo nos prueba Kant aue es esto lo cierto? Porque, dice, si les correspondiera algo fuera de nuestra subjetividad, tendría aue poder comprobarse por la experiencia empírica de los sentidos. Ahora bien, por su misma definición están fuera de toda posible experiencia sensible. Y nótese de paso que Kant no se limita a decir aquí que no se puede comprobar experimentalmente que a lo subjetivo le corresponda de hecho algo extrasubjetivo; sino que afirma sin más que no le corresponde nada. ¿No es esto dogmatismo?

Nosotros decimos que vemos en nuestra subjetividad verdades necesariamente eternas, que necesitan una base adecuada de subsistencia; y, que, al no encontrarla ni en las cosas que nos rodean, ni en nuestra propia "psiouis", deducimos como absoluta necesidad que más arriba de nosotros debe haber una base "física" para tales verdades. ¿Dónde está el dogmatismo?

Consta, por consigujente, que hay un objeto inteligible distinto de las mentes humanas, ya que él es único y las mentes muchas. Que su integridad no depende de aue las mentes le vean mejor o peor o que no le vean. Ese objeto inteligible es la Verdad inconmutable, enteramente libre de las trabas del espacio y del tiempo. Es eterna estrictamente y esencialmente superior a nuestra mente racional.

Por lo tanto, esa verdad que está a nuestra vista; pero muy por encima de nosotros nos indica perentoriamente que Dios existe.

"Tú mé habias concedido que si te mostrase algo que está por sobre nuestras mentes, confesarías que eso sería Dios, con tal de que no haya otra cosa más alta todavia. Porque si ha.y alguien más excelente aún, ese es Dios; y si no lo hay, la verdad misma sería ya Dios" ${ }^{39}$.

39. Tu autem concesseras, si quid supra mentes nostras esse monstrarem, Deum te esse 
Aquí termina San Agustín su demostración de la existencia de Dios. Pero nos quedan pendientes dos interrogantès interconexos que necesitamos aclarar:

1. Esa verdad inconmutable que ve nuestra mente racional, ¿es el mismo Dios? O en otras palabras, ¿vemos en ella directamente el ser de Dios?

2. En el caso contrario, ¿en qué consiste y dónde está esa luz, que no es Dios ni tampoco nuestra propia mente? $\mathrm{Y}$ en todo caso, ¿hay para nosotros un lazo lógico entre esa luz de nuestra mente y la existencia de Dios?

Como se ve, estamos en el centro de la gran cuestión de la iluminación agustiniana, que condiciona fundamentalmente su Programa vital: "noverim me, noverim te.".

Vamos a tratar el análisis de este problema centrándole en la "imago Dei" que tan genial y minuciosamente estudia San Agustín en sus libros "De Trintate".

\section{EL PROBLEMA DE LA ILUMINACION EN SAN AGUSTIN}

En lo que se refiere al primer interrogante, es completamente seguro que San Agustín nunca enseñó, ni hay indicios de que pensase en algún tiempo, que nosotros podemos en esta vida mortal y como de ley ordinaria, ver a Dios directamente en su propio ser. Es cierto que numerosos textos suyos, si se leen incautamente, parecen indicar algo parecido a una visión de Dios como medio necesario para nuestro conocimiento de verdades inconmutables. Entre otros muchos pasajes que pueden citarse al respecto, escogeremos dos o tres que parecen más significativos.

"La razón, que habla contigo, te promete mostrarte a Dios ante tu mente, como se muestra el sol a los ojos corporales" 40 .

Pero los ojos enfermos, y aun los sanos, no están hechos para mirar al sol directamente. Sólo pueden ver la luz del sol cuando está esparcida sobre los cuerpos oue ilumina. Y eso, tanto más perfectamente y con mayor comodidad, cuanto más sanos estén. San Agustín sabe que los ojos de nuestras almas están cargados de muchas impurezas que les estorban la visión del Sol divino, tanto directa, como indirecta. Algunas de tales impurezas son los vicios morales oue pueden irse eliminando más y más en esta vida. Los acentos con que San Agustín aspira a liberarse de estas manchas que ad-

\footnotetext{
confessurum, si adhuc nihil esset superius. Si enim aliquid est excellentius, ille potius Deus est: si autem non est, Jam ipsa veritas Deus est. (Ib. II, 15, 39, PL. 32, 1262).

40. Promittit enim ratio quae tecum loquitur, ita se demonstraturam Deum tuae menti, ut oculis sol demonstratur. (Sol. 1,6, 12, PL. 32, 875).
} 
vierte como obstáculos en su camino hacia Dios, hacen pensar a veces que creía bastar al alma una acabada pureza moral para poder ver a Dios aun en esta vida. Pero San Agustín no pensó eso nunca; porque sabia perfectamente que no sólo las impurezas morales constituyen un estorbo para la visión clara de Dios; sino que también es una traba de la mente humana en orden a la visión del Sol divino su unión natural con los sentidos corporales. $Y$ ese impedimento, lo sabía muy bien San Agustín, sólo puede ser superado en la vida futura, o tal vez merced a algún gran milagro que quisiere hacer Dios en favor de alguno de sus escogidos.

Sabía, pues, San Agustín perfectamente que mientras nuestra mente racional esté asociada en sus operaciones naturales con los sentidos, no podrá contemplar directamente al que es su propio Sol. Tan sölo verá su luz reflejada en las cosas due El ilumina. Los principios científicos de las ciencias son como la luz que el sol derrama sobre las cosas materiales para aue puedan verlas los ojos del cuerpo. En este sentido deben entenderse todos los pasajes que se refieren a este asunto. Por ejemplo:

"En aquella verdad eterna, a tenor de la cual todas las cosas temporales fueron hechas, vemos con la mirada de nuestra mente la forma según la cual somos, y acomodándonos a la cual obramos algo, sea en nosotros o en los cuerpos, según la verdadera y recta razón: y conservamos en nosotros a modo de "verbo" la idea verdadera de las cosas, que hemos tomado de allí" 41.

En este pasaje y otros semejantes San Agustín nos enseña como cosa del todo cierta, que la verdad que está como esparcida en los seres particulares de todas las cosas creadas, y la luz con que nuestra mente puede percibirla, tiene un origen único y primero, que es Dios. Pero no nos explica el modo concreto según el cual nos llega desde allí ni la "forma según la cual somos", ni la luz mediante la cual la vemos. En el pasaje de las Retractaciones, citado arriba en la nota 11, llama a "aquella verdad eterna", "luz de la razón eterna", que está presente aun a los imperitos de cualquier ciencia.

Está, pues, patente, según San Agustin, a toda mente humana, cultivada o ruda, la luz de la razón eterna; pero no el mismo sol que es la fuente original y única de tal luz. $Y$ no solamente no se puede demostrar que haya texto alguno en que San Agustín diga expresamente que vemos, o podemos ver directamente a Dios en esta vida cuando tenemos conciencia clara de que existen verdades eternas; al contrario, declara terminantemente varias veces que no podemos verle directamente; ni le vemos al percibir nuestras verdades:

41. In illa Igitur aeterna veritate, ex qua temporalia facta sunt omnia, formam secundum quam sumus, et secundum quam vel in nobis vel in corporibus vera et recta ratione aliquid operamur, visu mentis aspicimus; atque inde conceptam rerum veram notitiam, tanquam verbum apud nos habemus. De Trin. IX, 7, 12, PL. 42, 967). 


\begin{abstract}
"Nuestro modo de entender carnal... siente como puede las cosas verdaderas creadas; pero la verdad misma según la cual fueron creadas, le es imposible verla directamente - "intueri"-; porque si pudiera, jamás sería la luz del sol más clara que esto que vamos diciendo" ${ }_{42}$.
\end{abstract}

También tenemos un testimonio directo de su modo de pensar en esta cuestión en el libro de su mocedad filosófica, los Soliloquios; donde discurriendo acerca de cómo tendría que conocer a Dios para quedar plenamente satisfecho, y después de haber declarado que tal conocimiento debería ser mucho más perfecto del oue se tiene de un amigo, se pregunta si sería suficiente aue la certeza del conocimiento de Dios iguale a la que tiene el sabio geómetra de los principios de su ciencia. Sin atreverse a negar rotundamente, opone una dificultad que parece decisiva: si el conocimiento de Dios a que aspiramos fuese tan sólo como la ciencia que tenemos de estas cosas, el conocimiento de ellas nos proporcionaría el mismo gozo que esperamos recibir con el conocimiento de Dios. A lo que replica:

"Así es: mayor, mucho mayor será el gozo que te embargará cuando conozcas a Dics, que el proporcionado por el conocimiento de estas cosas; cero será esto a causa de la diferencia de las cosas conocidas, no de la certeza del conocimiento" 43 .

Por donde se colige claramente que ni las razones eternas de que habla San Agustín son Dios, ni las vemos en una visión directa de Dios. Pero aun cuando nuestras "razones eternas", nuestros axiomas geométricos, etc., no son visión de Dios, son, sin embargo, indicios ciertos de la existencia de Dios como origen primario de su posibilidad. Este es el sentido que debemos dar a las expresiones de San Agustín en todos los pasaies semejantes. Y él mismo nos invita con su ejemplo a seguir esta regla, a propósito de su discusión con Evodio mencionada arriba, pág. 9, nota 19. Después de su afirmación que parece terminante sobre la visión de Dios, y cuando Evodio se resiste a admitirla sin más, Agustín le aprueba, y declara que su intento es sólo mostrar algo que de tal modo sobresalga por sobre todo lo creado, que o bien eso sea ya Dios, o si se demuestra que debe haber algo más excelente todavía, eso sería Dios. En todo caso, la existencia de Dios queda asegurada para nuestro conocimiento:

Ev. "Confesaré de plano que es Dios lo que conste que no tjene sobre sí nada más excelente. Ag. Bien dicho, pues 10 que yo pretendo y es suficiente para mí, es demostrar que hay algo de tal naturaleza, que una vez admitido, tengas que confesar o que es Dios, 'o si hubiera otra cosa aún más excelente, esa será Dios... En todo caso... Dios existe" (v. 19).

42. Consuetudo carnalis vera quae creata sunt sentit ut potest; veritatem ipsam qua creata sunt non potest intueri; nam si posset, nullo modo esset lux ista corporea manifestior quam hoc quod diximus. (Ib. VIII, 1,2, PL. 42, 947).

43. Esto, plus te ac multo plus quam de istis Deo cognitio gavisurum: rerum tamen, non intellectus, dissimilitudine. (Sol. I, 5, 11, PL. 32, 875). 
Aclarada asi la primera cuestión, nos cae de lleno la difícil tarea de examinar la naturaleza de esa luz que ilustra nuestra mente cuando percibimos ciertas verdades de las oue tenemos el convencimiento pleno de que son eternas; y además, ¿cómo enlaza ese rayo luminoso nuestra mente con el foco original? El compromiso es grande, pues se trata de acotar el verdadero alcance de la doctrina agustiniana de la iluminación en el campo gnoseológico, y justamente nos encontramos en el punto donde se entrelazan los caminos del "Programa Vital": Dios y el alma. Si no acertamos a discernir bien estos lazos, permanecerán confusos los lineamientos del Programa.

San Agustín, como dicen sus comentaristas, nunca hizo ni trató de hacer una teoría sistemática del conocimiento. Con frecuencia señaló vigorosamente el hecho, para él evidente, de que sólo una verdad eterna y subsistente puede dar la razón de las verdades que nuestra mente racional alcanza a ver en su contorno como inmutables; pero dejó abierta la cuestión de cómo se generan tales verdades en nosotros; o sea, dejó sin aclarar el proceso mismo de nuestro conocer.

¿Cómo nace la "verdad" en nuestro espíritu? Para que esta pregunta tenga sentido, es necesario que nuestro espíritu experimente un contacto luminoso con el ser o los seres que nos rodean, haciéndose cargo de su existencia al conocerlos. Es decir, hablar de la verdad en nosotros, es reconocer due nuestro espíritu por su naturaleza tiene la maravillosa capacidad de conocer el ser de otras cosas y el ser de sí mismo; pues si de algún modo ha de brillar en él la verdad, es preciso que no sólo conozca a otros, sino que se dé cuenta de que tal conocimiento es suyo.

Es claro que no podemos emprender el estudio del conocimiento, sino comenzando por los hechos mismos; y sólo podremos fundamentar razonablemente los hechos de nuestro conocimiento, si analizamos la naturaleza de nuestro espíritu y sus posibles relaciones con el ser. San Agustín hace un profundo análisis de nuestro espíritu mediante los hechos del conocimiento, aunque no con propósitos gnoseológicos, sino buscando ejemplos con que aclarar las verdades de la fe cristiana acerca de Dios. En este empeño ha aportado muchas luces en torno del problema gnoseológico; pero no lo cerró definitivamente. Son muchísimos los comentaristas del pensamiento agustiniano sobre este asunto; pero, según parece, nadie ha tratado de completar el estudio hecho por San Agustín sobre los datos del problema, con el fin de acercarse algo más a la solución definitiva. ¿Será demasiada audacia de mi parte intentarlo siquiera? En todo caso busco la verdad, lo que nunca desagradó a San Agustín. 


\section{LA MENTE HUMANA,}

Vamos a seguirle paso a paso en su maravillosa discusión sobre la mente humana desarrollada en su "de Trinitate"; pero con el objeto de ayudarnos en su inteligencia y aun de añadir alguna cosa tal vez nueva, mas no contradictoria con su pensamiento, vamos a establecer antes claramente la distinción que hay entre 10 que es la mente racional en su "ser" y lo que es en "sus operaciones". Quizá seguiriamos meior los gustos modernos designando esta zona operacional del alma como su "existir". Tratamos, pues, de puntualizar la diferencia entre el "ser" y el "existir" de nuestra alma racional. Parece enteramente obvia esta distinción; pero seguramente no se ha advertido su posible utilidad, ni se ha reparado en su alcance; y por eso, nadie que yo sepa, se ha fijado en ella en relación al menos con nuestro objeto. Sin embargo me parece indudable su importancia para el debido esclarecimiento de algunos puntos oscuros.

Distinguiremos, pues, en nuestra alma racional dos "faces" o "vertientes". Es exactamente la misma dicotomía que establecimos en nuestro libro "El Sistema Esencial de la Materia" para los entes materiales, donde separamos cuidadosamente la "faz interna" o esencial del ente, de su "faz externa" operacional. Esta distinción se revela como de una importancia extraordinaria para explicar la verdadera naturaleza del ente material, tanto en el citado libro impreso, como en otro no publicado aún, en el que se desenvuelven convenientemente las ideas filosóficas contenidas en el primero. Espero que aplicada debidamente al alma humana y sus operaciones mentales, nos ayudará eficazmente a comprender la doctrina agustiniana sobre nuestra mente racional: "Imago Dei"; y aun tal vez a completarla en algo.

No se trata por supuesto de la distinción que hay en el compuesto humano entre el alma y el cuerpo. Tampoco entre el conocimiento racional y el conocimiento sensible. Hasta podría suscitarse el problema de si hay en nosotros, además del cuerpo material y el alma espiritual, un "ouid medium" biológico que ni es propiamente materia, ni propiamente espíritu; pero no es ése nuestro asunto. La distinción de "faz interna" y "faz externa" aplicada al alma racional debe centrarse y contraerse a la parte espiritual simple oue hay en nosotros y es el asiento de nuestro conocimiento racional. En ese elemento unitario que entra en la composición de nuestra entidad humana, debemos tener siempre presente lo que constituye su esencia física individual, "faz interna", sin confundirla con sus operaciones, que siempre se realizan hacia fuera de lo intimo de nuestro espiritu, y que, aun cuando sean internas con respecto al compuesto humano, son externas con relación a la esencia física 
interior de que hablamos; y por eso decimos que forman entre todas sin excluir ninguna "la faz externa" del alma racional.

La entidad simple racional creada por Dios, es la "faz interna": "mens". Las múltiples operaciones conscientes de la criatura racional, son la "faz externa": "cogitationes".

Me parece que establecida así esta distinción, clara de suyo, no admite objeciones, y puede sernos utilísima para ordenar nuestros pensamientos en torno al problema de la "iluminación". Por lo pronto, nunca olvidemos que, si bien son dos faces o caras distintas, pertenecen siempre a la misma entidad.

Podriamos destacar más claramente el carácter de la "faz interna" de nuestra alma racional comparándola con la del ente material primario que hemos analizado en los libros mencionados arriba. Al fin y al cabo, pienso que todas las criaturas salidas de las manos de Dios deben ostentar en lo íntimo de su ser ciertos rasgos comunes a modo de vestigios más o menos claros que ha dejado en ellas el Creador. Allá decíamos que la "faz interna" del ente primordial de la materia está constituida por una virtud o fuerza que desarrolla su actividad en "espacio y tiempo". Por modo semejante podemos decir aquí que la "faz interna" del espíritu humano es una fuerza plasmada en "inteligencia y voluntad". No es inteligencia $\mathrm{y}$ voluntad en el acto de querer y entender estas o las otras cosas; sino capacidad activa radical para querer y entender. Esa virtudo fuerza radical inteligente y amante, es una "acción" del Creador comunicando el ser a nuestro espíritu en la medida por El tasada; mucho más execelente, por cierto, que la usada para el ente material. Es, pues, nuestra mente racional una "acción divina", que constituye su esencia o "faz interna", dotada de actividad propia que desarrollará ulteriormente en su "faz externa"; o sea, en el conjunto de todas las operaciones en que manifiesta su existencia.

Anotaremos aquí otra distinción, que ya hemos usado antes alguna vez. Se relaciona con la anterior y puede sernos de provecho tener buena cuenta de ella. Me refiero al binomio "fisis-noesis". Naturaleza de algo que existe de suyo: "fisis"; la región del pensamiento: "noesis". Su distinción es clara y sus relaciones indisolubles. Este doble juego de separación y de unión, debe ser considerado desde dos puntos de vista muy diferentes. $1 .^{\circ}$ Entre la cosa conocida, "fisis", y el conocimiento de la cosa, "noesis". La cosa conocida existe de suyo, y es o puede ser una naturaleza subsistente. El conocimiento, en cambio, sólo existe en la mente que conoce y no subsiste de suyo. Tenemos: "fisis-noesis": objeto-subjetividad.

2. punto de vista. Naturaleza cognoscente, "fisis"; los actos del conocimiento, "noesis". El cognoscente o sujeto subsiste de suyo, los actos del conocimiento no pueden existir separados del sujeto cognoscente. "Fisis-noesis": sujeto-subjetividad. Es, pues, bien neta la diferencia entre los términos del binomio. 
En cuanto a sus relaciones, nos interesan aquí las que podriamos llamar relaciones "físicas"; o sea, las que intervienen en la existencia misma del binomio. Por supuesto que la "noesis" de que hablamos es exclusivamente la nuestra, la que florece en la mente racional humana. Esta "noesis" no puede existir sino en función de una "fisis", que por lo que acabamos de decir, vemos que puede tener un doble carácter: la "fisis" del objeto conocido, y la "fisis" del suieto cognoscente. Lo oue importa hacer notar ahora especialmente es que la "noesis" no puede relacionarse físicamente con el objeto si no es a través del sujeto cognoscente. La "noesis" se relaciona física y directamente con su sujeto, y sólo mediante su sujeto, con los demás objetos. Los dos pares del binomio pueden combinarse en ángulo; pero no en triángulo. En efecto, no hay combinación triangular "objeto-noesis-sujeto", poroue no hay comunicación directa entre la "noesis" y su objeto. La circulación es: "objeto-sujeto-noesis", y "noesis, sujeto, objeto". La "noesis" sólo puede relacionarse con su objeto a través del sujeto.

Teniendo bien en cuenta todo esto, continuaremos nuestro trabajo. Como es sabido, San Agustín, en su tratado "De Trinitate", hace un análisis genial de la mente humana buscando en ella aquella "imagen de Dios" de que habla la Biblia, en la que espera encontrar algún reflejo aclaratorio del misterio cristiano de la Sma. Trinidad. Vamos a escucharle con filial respeto, lo cual no ha de impedirnos intercalar nuestros propios comentarios.

El análisis aludido se inicia en el libro IX y se prolonga casi hasta el final de la obra. Comienza por el hecho evidente de que el alma racional se ama a sí misma, y deduce sin más que también tiene que conocerse:

"No podría amarse la mente a si misma, si no se conociese también" "4.

Pero la mente, que recoge las noticias que tiene de las cosas corpóreas por los sentidos, sólo puede comunicarse con las incorpóreas por sị misma. Luego se conoce a sí misma por sí misma:

"Luego se conoce a sí misma por sí misma, (y no por los sentidos), por cuanto es incorpórea" 45

En estas operaciones podemos distinguir tres notas en el alma, a saber: Mente, conocimiento y amor, que forman un núcleo apretadísimo e indivisible, sin confundirse, no obstante, mutuamente; sino que conservando cada cual su propia fisonomia, completan un sistema esencial perfecto. 962).

44. Mens enim amare se ipsam non potest, niși etiam se noverit. De Trin. IX, 3, 3, PL.42, 45. Ergo et semetipsam per se ipsam novit, quoniam est incorporea. (Ib. PL. 42, 963). 
"Se nos indica que... estas cosas (mente, noticia, amor) existen en el alma, y que estando en ella como envueltas en un capullo, a fin de que podamos comprenderlas y contarlas, se desenvuelven, por así decirlo, substancialmente, esencialmente, no como pegadas en un sujeto, a modo del color..." 46.

Son pues substancia la mente amante, substancia la noticia y substancia el amor; pero son relativos entre sí.

"Pero el amante y su amor, el cognoscente y su ciencia se enuncian en relación consigo mismo" 47

Exactamente como las notas que forman un sistema esencial propiamente dicho; que no se confunden entre sí, pero que tampoco existen sino apoyándose mutuamente. Pero además, sólo forman una sola esencia.

"Y no veo cómo podría ocurrir que esas tres cosas no sean de la misma substancia; siendo así que es la misma mente la que se ama y se conoce" ${ }^{48}$.

Insiste San Agustín en la importante propiedad de estas tres notas que forman la esencia del alma racional humana, a saber:

"En aquellas tres cosas, la mente conociéndose y amándose, hay firme una trinidad: mente, amor, noticia, sin confusión de ningún género; aunque cada cual está en sí misma y toda entera en todas las otras" 49.

Esta distinción neta de las notas que forman un sistema esencial perfectamente unitario, y por lo mismo, sin que puedan subsistir separadas, es la distinción propia de los entes "primarios"; o sea, los que salen directamente de las manos del Creador.

Es de advertir que San Agustín se refiere aquí al conocimiento y amor que la mente tiene directamente de sí misma sin intermediarios; o sea, sin el auxilio, digamos, de otros conocimientos de cosas exteriores; ya oue eso le interesa especialmente en su búsaueda de la "imago trinitatis" en el alma. Sin duda San Agustin no tiene nresente en ningún caso la distinción que nosotros usamos de las dos "faces" en el alma racional; pero es evidente que en estos pasaies su intención se dirige hacia lo oue nosotros llamamos la "faz interna", la única en la que por fin hallará la imagen trinitaria de Dios. Sin embargo, por lo mismo de no haber separado de una vez ambas "faces", repetidamente tropieza con puntos entrelazados pertenecientes a una $u$ otra; que necesariamente dejan su rastro en no pocas

46. Admonemur... haec (mens, notitia, amor) in anima existere, et tanquam involuta, evolvi ut sentiatur et dinumerentur substantialiter, vel ut ita dicam, essentialiter, non tamquam in subjecto, ut color... (Ib. IX, 4, 5, PL. 42, 963).

47. Sed amans et amor, aut sciens et scientia relative ad se dicuntur. (Ib. IX, 4, 6, PL. 42, 964).

48. Quomodo autem illa tria non sint eiusdem substantiae, non video; cum mens ipsa se amet et ipsa se noverit. (Ib. IX, 4, 7, PL. 42, 964).

49. At in illis tribus cum se novit mens et smat se, manet trinitas: mens, amor, notitia; et nulla commixtione confunditur: quamvis et singula sint in semetipsis, et invicem tota in totis. (Ib. IX, 5, 8, PL. 42, 965). 
ambigüedades. Casi a renglón seguido se ve obligado a considerar cosas de la otra "faz", de la que no puede desprenderse, naturalmente, y ve en ella algo que ciertamente no está en buen acuerdo con su oficio de imagen de Dios. Cuando la mente humana se conoce y ama a sí misma, ama y conoce algo que está muy lejos de aquella serena inmutabilidad propia de las cosas divinas.

"Pero cuando la mente humana se conoce y ama a sí misma, no conoce y ama algo que sea inconmutable: cada hombre cuando habla manifiesta su mente atendiendo a lo que de momento pasa en ella de una manera muy distinta de como lo haria si tratara de definir lo que se entiende por mente humana con una idea especial o genérica" ${ }^{50}$.

Están aqui perfectamente delineadas y separadas las dos "faces" del alma: "aliter quid in se ipso agatur attendens", atendiendo a lo que de momento pasa en ella; o sea a sus pensamientos actuales, reflexiones, etc., la parte operatoria de la mente: su "faz externa". "Aliter humanam mentem definit", define lo que se entiende por mente humana; es decir, piensa en la definición de su esencia, la "faz interna". Sin embargo, no se nota tendencia alguna en el sentido de hacer un uso posible de esta distinción para explicar la inconmutabilidad de las verdades percibidas por nosotros.

Parece hasta obvio que la turbulencia y movilidad de la "faz externa" del alma no tiene por qué turbar la calma de que posiblemente goza su "faz interna". Al fin y al cabo, aquélla está entregada a las pasiones y disputas de los hombres; mientras que ésta constantemente está en las manos del Creador. Pero San Agustín, impresionado por la evidente volubilidad de los pensamientos de la mente humana, no encuentra en ella salida clara a la inconmutabilidad de las verdades eternas. Por eso dice a continuación que hay cosas, nuestros pensamientos particulares, que sólo existen y vemos en nosotros mismos, de las cuales los demás podrán saber sólamente mediante la fe en nuestras propias palabras; y otras que vemos en la verdad misma, "in ipsa veritate", las que pueden ver todos por sí mismos sin necesidad de que se las mostremos nosotros. Las unas se mudan con el tiempo; las otras son eternas, y concluye:

"Intuimos la verdad inviolada, de la cual sacamos... cómo debe ser la mente humana según las razones sempiternas" ${ }^{51}$.

También el conocimiento de las cosas sensibles está sometido a reglas que lucen por encima de los sentidos, muy diferentes, por cierto, de las meras impresiones sensibles:

50. Sed cum se ipsam novit humana mens et amat se ipsam, non aliquid incommutabile novit et amat: aliterque unusquisque homo loquendo enuntiat mentem suam, quid in se ipso agatur attendens; aliter autem humanam .mentem speciall aut generali cognitione definit. (Ib. IX, 6, 9, PL. 42, 965).

51. Intuemur inviolabilem veritatem, ex qua... definiamus... hominis mens qualis esse sempiternis rationis debeat. (Ib. IX, 6, 9 ,PL. 42, 966). 
"Nos vemos obligados a admitir, que, cuando aprobamos - reprobamos algo rectamente en nuestra íntima conciencia, lo hacemos ajustándonos a reglas muy distintas (de toda percepción sensible), que permanecen incorruptas por encima de nuestra mente..., de suerte que el modo de concebir en nuestra fantasía, o de ver los cuerpos por los sentidos, es enteramente distinto de la simple inteligencia con que percibimos más arriba del vértice de nuestra mente las razones y el arte inefablemente hermoso que preside la formación de tales figuras" 52

Hay, pues, reglas eternas de conocimiento que de ningún modo pueden tener su fundamento en la región cambiante del pensamiento humano, y que exigen perentoriamente una base ontológica más firme que aquella en que se apoyan los propios pensamientos humanos. Pero tenemos que distinguir cuidadosamente entre la parte existencial de estos pensamientos, que arraiga y se fundamenta en la "psiquis" que los engendra; y su parte lógica que apunta a la verdad que expresan, cuyo fundamento ontológico bien pudiera estar más allá de la "psiquis" humana. Por eso San Agustín, cuando se trata de pensamientos que expresan verdades eternas, pide para ellos con razón inapelable una base ontológica que esté muy por encima de las posibilidades de nuestro ser.

Ahora bien, es fácil que en esto se nos mezcle subrrepticiamente una confusión perniciosa, si admitimos sin crítica que nuestros pensamientos, cuya raíz óntica existencial está en nuestra alma, no pueden reflejar la inconmutabilidad de algunas verdades si no vemos directamente el fundamento ontológico que las sustenta. Justamente aquí es donde se nos plantea el problema central de nuestra "noesis". ¿Cómo es posible que nuestros pensamientos cuya base óntica no es eterna, pueden ser iluminados con luces de eternidad? ¿Cómo surge en ellos el resplandor de la verdad imperecedera? Parece indudable en todo caso, aue nosotros vemos tales verdades "super aciem mentis simplici intelligentia capientes". Desde luego que, siendo el pensamiento, "noesis", distinto del "ser" que se muestra en el pensamiento, no se ve, al menos de inmediato, que haya contradicción en admitir que en un pensamiento fugitivo pueda aparecer la visión de una verdad imperecedera; pero resulta tarea no poco ardua el explicar cómo puede suceder tal cosa; y más cuando ya está concedido que no es visible directamente para nosotros el "Ser", fundamento necesario y único posible de todo $10 \mathrm{im}-$ perecedero.

¿Cómo captamos nosotros con nuestros tornadizos pensamientos esas verdades inconmutables? Es preciso, nos dice San Agustín,

52. Alis omnino regulis supra mentem nostram incommutabiliter manentibus, vel approbare apud nosmetipsos, vel impiobare convincimur, cum recte aliquid approbamus aut reprobamus... Aliter figurantes animo imagines corporum," aut per corpus corpora videntes; aliter autem rationes artemque ineffabiliter pulchram talium figurarum super aciem mentis simplici intelligentia capientes. (Ib. IX, 6, 10-11, PL. 42, 966-967). 
que lancemos la mirada de nuestra mente desde lo que en ella se aleja más de los sentidos, a fin de poderlas ver con un acto de inteligencia lo más simple posible purificada de todo rastro de sensibilidad. "Super aciem mentis"; es decir, más allá, más arriba, más adentro que nuestro acto racional "cogitativo" más espiritual posible. Recordemos que todos nuestros actos cogitativos pertenecen a la "faz externa" de nuestra alma racional. Cuando, pues, siguiendo la indicación de San Agustín, y dando la espalda a todo el mundo sensible, nos ponemos a reflexionar sobre la naturaleza de las verdades que brillan, por ejemplo, en los axiomas de las ciencias, tenemos más allá y más adentro de esta actitud de nuestra mente la "faz interna" de nuestra propia alma. Es necesario, nos dice San Agustín, que "esos inteligibles" se nos muestren en una naturaleza incorpórea:

"Los inteligibles se muestran a las miradas de nuestra mente en alouna naturaleza incorpórea, del mismo modo que las cosas visibles o palpables se muestran cada una en su lugar a los sentidos del cuerpo" ${ }^{53}$.

Se ve, pues, que San Agustín exige para la "noesis" una base "física", no ciertamente dando a esta palabra un sentido precisamente corpóreo; sino simplemente el significado de una naturaleza que existe de suyo. De seguro que no pensaba al escribir esto en que tal naturaleza incorpórea bien podría ser justamente nuestra propia alma racional en lo que nosotros llamamos su "faz interna". Pero, ¿ por qué no habría de ser ese nuestro nucleo interno el lugar apropiado donde se concentra para nosotros la luz que originalmente procede de Dios como de su fuente primera? Sabemos oue no nos es dado contemplar directamente el foco originario. Pero ¿es siquiera verosimil que la luz primaria tenga que adensarse en algún modo de concentración intermediaria para hacerse visible a nuestra mente?

El P. Tirso Alesanco, en el número extraordinario del año 1968 de la revista "Augustinus", en su importante artículo sobre "Metafisica y Gnoseología del Mundo inteligible" según San Agustín, dice en la pág. 29: "Las verdades inteligibles son objetos de naturaleza espiritual alumbrados, iluminados o irradiados por la luz increada en su actividad ad extra, en un mundo que está al alcance de la inteligencia humana". El P. Alesanco ha declarado pocas líneas antes que "los inteligibles no son. subsistentes". Pero entonces, si "son objetos de naturaleza espiritual" que, como se da por sabido, no están en Dios, ni tampoco en el alma racional, sino tan sólo a su disposición para que los vea, ¿cómo debemos entenderlos? ¿Hemos de admitir que esa luz, una vez salida de Dios, se convierte en criatura es-

53. In natura incorporali sic inteiligibilia praesto sunt mentis adspectibus, sicut ista in locis visibilia et contrectabilia corporis sensibus. (Ib. XII, 14, 23; PL. 42, 1010). 
piritual y eterna, que nuestra mente puede ver o puede no ver; pero en todo caso y sea cual fuere su naturaleza, es un "quid" intermediario entre Dios y nosotros?

Todo esto resulta demasiado inverosímil, y desde luego me parece que no concuerda con el pensamiento agustiniano. Así como la luz del sol material fuera de su foco o del cuerpo iluminado es invisible en sí misma, de modo semejante la luz gnoseológica, separada de su foco irradiante y del cognoscente que la recibe, es también invisible. $Y$ en este caso esto significa, no sólo insubsistente, sino simplemente no existente. En la iluminación agustiniana para el conocimiento de las reglas y verdades eternas, no hay intermediarios entre Dios y nuestra alma. Ningún texto de San Agustín lo sugiere; al contrario, los tiene claramente opuestos. A propósito de nuestro Mediador el Verbo, escribe:

"Como Maestro digo, para que las cosas verdaderas... fuesen confirmadas con su autoridad manifestada en la carne en favor de quienes no podian verlas ni discernirlas en la misma íntima Verdad, que aun antes de asumir al hombre, estaba presente Ella misma a cuantos pudieron participar de Ella. Y sobre todo con el ejemplo de su encarnación, nos convenció de una gran verdad. En efecto, como la mayor parte de los hombres... pensaron en acercarse a Dios... por medio de las potestades celestiales..., con su encarnación hizo comprender a los hombres que tan cerca de su piedad está Dios... que se dignó tomar al hombre" ${ }^{54}$.

Nada hay, por tanto, fuera de la Verdad increada, en que nosotros podamos ver las verdades inconmutables como desde lejos. Más claro, aún lo dice en "De Trinitate":

"Esta imagen de Dios es tan poderosa, en sí misma, que tiene virtud para unirse a Aquel cuya imagen es. De tal suerte está colocada en el orden, no local, de los entes naturales, que nor encima de ella sólo está El". O sea, entre ella y El no hay nada ${ }^{55}$.

En suma, las verdades inteligibles de que tratamos no pueden ser objetos de ninguna clase colocados fuera de Dios y fuera del alma racional.

El P. Alesanco nos dice que "es cierto que San Agustín emplea, a veces, la palabra "iluminación" para designar la acción por la que Dios crea la inteligencia humana". Pero añade que los textos en este sentido "no debilitan en nada la interpretación anterior de la iluminación agustiniana". ${ }^{56}$

54. Ep. $137,3,12$, PL. 33, 520-521).

55. Quae in se imagine Dei tam potens est, ut ei cujus imago est valeat inhaerere. Sic enim ordinata naturarum ordine, non locorum, ut supra illam non sit nisi llle (De Trin. XIV, 14, 20. PL. 42, 1051).

56. En Augustinus, ( = strenas Augustinianas P. Victorino Capanaga, oblatos-philosophica), 1968,29 
Así será, pero con esta explicación el P. Alesanco reconoce que tampoco abonan la idea de un objeto inteligible no subsistente exterior a Dios y al alma racional.

Yo creo que mejor que buscar paliativos para las aparentes divergencias y vacilaciones del pensamiento agustiniano al respecto de la cuestión que nos ocupa, sería preferible descubrir algo que está oculto trayendo al medio lo que se echa de menos, en donde puedan concentrarse todas las expresiones agustinianas, no para corregirse mutuamente, sino para aclararse y fortalecerse. Es de admirar cómo San Agustín afirma rotundamente cuando está seguro, y donde no, se queda indeciso. Por eso, no es de temer encontrar en él contradicciones. Ese algo que se presiente en la exposición agustiniana, pero que tenazmente se mantiene oculto, no es otra cosa, según creo, que la "faz interna" del alma racional netamente discernida, aunque no escindida, de su "faz externa".

Lo oue necesitamos para comprender que esto tiene que ser así, es entender correctamente lo que es esa "faz interna" en relación con su "faz externa". La "faz interna" es la esencia física del alma que está saliendo directamente de las manos del Creador. "Está saliendo". No salió un día para existir después aislada e independiente. Dios la crea y de continuo la conserva en su ser físico. Ese ser físico o "esencia física" se mantiene siempre en el modo como la "está haciendo" el creador. Es "acción" del creador, y en cuanto tal, depende rígidamente del creador. Ahora bien, esto no quiere decir que sea inerte de suyo; y he aquí el nudo de no pocas confusiones. La "esencia física" o "faz interna" del alma, es una acción de Dios que la crea. Como acción de Dios sólo está sujeta a la voluntad de Dios; pero además es una criatura dotada de actividad. Esta es propiedad suya, puesto que Dios se la ha dado. Y se la ha dado como dote incluida en la naturaleza de la "acción" con que la crea. El alma, al hacer uso de esta acividad suya, se despliega en su "faz externa", de la que es responsable. Aquí resuena el eco de la conocida frase agustiniana: "Quien te creó sin ti, no te salvará sin ti".

Por lo tanto, toda la actividad propia del alma racional humana se realiza con estrecha dependencia ciertamente de la "faz interna"; pero sin perturbarla en su esencia que está a las órdenes exclusivas del Creador. Es necesario, pues, separar lo que es obra de Dios, la "faz interna", de lo que es obra de la obra de Dios, "faz externa".

No es ni mucho menos una sutileza esta distinción. Por el estudio del ente material que hemos hecho en las obras citadas arriba, se ve cuán necesario es separar en su estudio las dos "faces" o "vertientes" de dicho ente, a fin de poder introducir un rayo de luz en la explicación de las propiedades íntimas de la materia. Lo mismo ocurre al desdoblar los pliegues interiores del espíritu. A San 
Agustín le conturba la dualidad oue observa en el espíritu del hombre. Comprende perfectamente 10 que es bueno de suyo, siendo asi que él es malo. Ve destellos evidentes de eternidad en las verdades inconmutables que contempla dentro de sí mismo, y él se siente mudable ¿Cómo es posible que todos los hombres comprenden perfectamente qué es la justicia, siendo con frecuencia ellos completamente injustos?

"Conocemos dentro de nosotros y en nosotros en qué consiste ser justo. Pues cuando busco lo que he de decir para hablar de eso, ciertamente no lo encuentro sino dentro de mí mismo" 57 .

"Es cosa sorprendente que el alma vea en sí misma lo que nunca vio en otra parte, y vea la verdad, y vea dentro de sí misma la justicia del alma que está viendo, siendo ella misma alma, pero no alma justa" ${ }^{57}$.

Los mismos impíos piensan a veces en la eternidad, y reprenden o alaban rectamente muchas cosas. ¿Con qué reglas se dirigen cuando hacen esto? Pues parece del todo inverosímil que tales re glas y verdades eternas tengan su fundamento propio en lo que constituye la naturaleza humana, que da muestras indudables de versatilidad.

"¿En dónde las ven? Pues es imposible que sea en su propia naturaleza siendo así que, fuera de toda duda, tales cosas se ven con la mente, y consta con certeza que sus mentes son mudables" 58 .

La actividad reflexiva racional de nuestra mente pertenece a la "faz externa" del alma. Es indudable que en esta vertiente donde se muestra tan resaltante su mutabilidad, su justicia e injusticia, su ciencia e ignorancia, no puede encontrarse la razón inmóvil de las verdades eternas. Desde luego también podemos añadir que tampoco en la "vertiente interna", de la que al fin, la externa es un reflejo, pueden arraigar tales verdades como en su suelo propio y estrictamente originario. Mas ¿por qué, aun no teniendo en ella su primer origen, no han de poder encontrar una sede adecuada en ella? Sabemos, en efecto, que el Creador la ha hecho capaz de percibirlas y, por lo tanto, de contenerlas de alguna manera. Es claro de suyo que no es lo mismo percibirlas que contenerlas; pues bien sabemos que es preciso evitar cuidadosamente la confusión entre "noesis", de quien es el "percibirlas", y la "fisis", a quien corresponde el "contenerlas". Pero sabemos también que la "noesis" exige una base suficiente en la "fisis", sin la que no podría darse. Y

57. In nobis igitur novimus quid sit justus. Non enim alibi hoc invenio, cum quaero ut hoc eloquar, nisi apud me ipsum. Illud mirabile est ut apud se animus videat, et sit ipse, animus et non sit justus animus, quem apud se ipsum videt... An illud quod videt veritas est interior praessens animo qui eam valet intuere? De Trin. VIII, $6,9, \mathrm{PL} .42,955)$.

58. Ubi eas vident? Neque enim in sua natura, cum proculdubio mente ista videantur, eorumque mentes constet esse mutabiles. (Ib. XIV, 15, 21, PL. 42, 1052). 
creo que, justamente una "fisis" constituida según el bosquejo que hemos delineado para la "faz interna" del alma racional humana, da perfecta cuenta de nuestra "noesis" en acuerdo con la teoría general agustiniana.

Reflexionemos. La esencia física del alma racional sale de las manos del Creador con dones tan excelentes, que es capaz de hacerse cargo de verdades eternas comprendiéndolas. El "ser" que está recibiendo es luminoso. Todos los seres, aun los materiales, que salen de las manos de Dios son luminosos; y no me refiero al significado material de la luz, sino a su sentido metafórico en cuanto se muestran en la verdad. El ser del alma racional humana es doblemente luminoso, por cuanto no sólo puede ser visto, sino también puede ver. Este ser excelentemente luminoso, debe considerarse como pasivo con respecto a Dios, y como activo en relación a lo que hemos llamado su "faz externa" o vertiente operacional. Por consiguiente toda su luz la recibe directamente de Dios; pero no a modo de visión sino a modo de creación. Y podríamos preguntarnos aqui, ¿hay algún modo más excelente y propio de Dios para comunicar su luz a quien quisiere que ese que consiste en crearlos? Más aún, no es posible ningún otro si no precede éste, no sólo como condición pasiva meramente, sino como preparación activa que fundamente cualquier posibilidad posterior. En efecto, la "faz interna" del alma es la fuente activa de todas sus operaciones, tanto cuando da, como cuando recibe algo a través de los sentidos corporales.

Ahora bien, en lo que más excelentemente se destaca esta actividad operatoria de nuestra alma es en su "acies mentis", en su mirada racional consciente, que en cuanto actividad humana, debe ser entendida como acto que pertenece a la "faz externa". Se comprende, pues, perfectamente que nuestra mirada racional, como acción del momento que es, no tiene contacto directo con el foco luminoso central originario. En realidad, ni siquiera podemos ver directamente la "faz interna" de nuestra propia alma, aun cuando empeñemos en ello el más profundo y eficaz esfuerzo reflexivo. Sería ver la mano operante del Creador; pero tal como vivimos en esta vida no nos es dado "presenciar", asistir como espectadores a la obra creadora. Si pudiéramos contemplarla en nuestra "noesis" tal cual es, ¡cuántas nieblas se disiparian en nuestro horizonte gnoseológico!

Sin embargo, la "faz interna" de nuestra alma racional es, por definición, el fundamento, condición y presupuesto activo de toda nuestra experiencia gnoseológica. Si lográsemos comprender bien esto, creo que se aclararía notablemente el problema gnoseológico, tratado siempre por los filósofos y siempre replanteado de nuevo. Las luces que San Agustín esparció en torno de esta cuestión nos van a facilitar la tarea.

Es importante sacar al medio aqui lo que dejamos establecido 
arriba, y que si lo dejamos pasar inadvertido, puede ocasionar en nuestro razonamiento no pequeños tropiezos. El mundo de nuestro pensamiento, nuestra "noesis", no tiene lazo de unión alguno con nuestro exterior, sino es por el intermedio de nuestra "fisis". Ahora bien, nuestra "fisis" no es sencilla. Tiene una parte espiritual y otra material. Esie hecho complica extraordinariamente nuestro panorama gnoseológico. Este es de suyo totalmente interno sin que pueda salir de nuestra mente; pero tiene una doble referencia a lo que no somos nosotros. La una va hacia abajo por intermedio de los sentidos corporales; la otra hacia arriba mediante la "faz interna" del alma. Huelga decir que ambas referencias son heterogéneas entre sí; pero no enteramente ajenas. Hay entre ellas dependencia mutua, y justamente en el nudo de tal interdependencia se abren nuestros ojos a la "noesis".

En nuestro estado actual, los ojos de nuestra mente están abiertos hacia la vertiente externa del alma racional. Tienen delante el mundo que le presentan los sentidos corporales; y detrás, la "faz interna". Su relación con esta "faz" consiste en que de ella reciben su capacidad para ver. No está ella en el foco de la visión actual; pero gracias a ella, y sólo por ella, puede apreciar y juzgar lo que viniendo de fuera aparece en el foco de su visión. Cuando esto acontece, es decir, cuando la mente entra en acción viendo o conociendo, no sólo se da cuenta de que hay al frente algo que no es ella, sino que también tiene un testimonio claro de sí misma, o sea, de la esencia en que radica su "faz interna".

En la interacción no homogénea, esto es, en la concurrencia de dos acciones pertenecientes a entidades de distinta jerarquía ontológica, a saber, la que viniendo de los objetos exteriores nos entra por los sentidos, y la que sale a su encuentro desde la "faz interna" de nuestro espíritu, se realiza la visión cognoscitiva, cuyo horizonte alcanza tanto a la zona externa de la sensibilidad, como a la zona interna del espíritu. Pero de modos muy diversos, por lo mismo que la interacción es heterogénea. La visión misma, "noesis", aunque a primera vista aparezca como un "quid" neutral entre ambas acciones, no es así de ningún modo. La visión cognoscitiva es propiedad estricta del espíritu, si bien mira a su "faz externa", ya que el conocimiento racional consciente es la "faz externa" del espíritu que él domina desde su "faz interna".

No hay que confundir este dominio con el que tiene el alma sobre el cuerpo al que informa. Es claro oue el cuerpo no pertenece al alma como siendo parte de su propia naturaleza, ni a la "faz interna" ni a la externa. Si además del cuerpo estrictamente material, hay en el hombre algún elemento biológico, que arrastre incluso consigo alguna clase de sensibilidad, y no pertenezca a ninguna de las dos "faces" del espíritu, es cuestión interesante que no tratamos aquí. De todos modos, debe tenerse presente que, aun en el caso de 
que hubiere algo de eso estrictamente excluido de ambas "faces" del espiritu, siempre sería parte integrante de la entidad humana, en íntima colaboración con las demás. San Agustín no parece admitir apartamientos de esta clase en el compuesto humano fuera del alma y del cuerpo. Sin embargo, a veces habla de manera que pudiera serle útil tal distinción. Así, cuando se refiere a aquella parte nuestra que, al ocuparse de las cosas temporales, obra de tal modo, que no puede considerarse como común entre nosotros y las bestias, afirma que es racional indudablemente y pertenece a nuestra substancia racional, aun cuando se considere como una parte tomada de esa substancia racional y separada para que se ocupe de la administración de lo sensible ${ }^{59}$. Pero, ¿no habrá también en nosotros alguna cosa sensible que tienen, asimismo, las bestias?

"No solamente el cuerpo ha de tenerse como el hombre exterior, sino también cierta cosa vital qu vigoriza la unión de los miembros del cuerpo, y se extiende a todos los sentidos que posee para percibir las cosas exteriores" ${ }^{60}$.

Como quiera que sea, esta cuestión no es importante para nuestro asunto.

Lo que ahora nos importa tener bien en cuenta es que nuestra actividad mental cogitativa pertenece a la "faz externa" racional, por cuanto es acción nuestra, y no acción directa de Dios, como la "faz interna". Por lo tanto, podemos decir que nuestra "acies mentis" mira hacia afuera en su estado natural, y ve los objetos externos como intuyendo, mientras a su propio espíritu lo conoce sólo reflexionando. Pero además de esta visión refleja, más o menos acabada que podemos adquirir de la "faz interna" de nuestra alma con un trabajo penoso, hay otra función gnoseológica propiamente suya, que nos interesa considerar especialmente. La "faz interna" no es término de nuestra visión, sino su principio activo. Substancia suya, por así decirlo, y no mera condición necesaria.

Hemos dicho que la "faz interna" es una acción conservativa del Creador, que podemos designar perfectamente como "iluminación" constitutiva de calidad tan excelente, que de ella surge esa luz racional cognoscitiva que nos permite contemplar verdades con rango de eternidad. En este modo de discurrir hay algo de metafórico, pero es fácil reducir los términos a su significado propio. La creación del alma es una iluminación que a su vez queda constituida en foco iluminante. Ya se entiende de suyo que es luz racional la que irradia. $Y$, ¿cómo lo diremos? no es aún nuestra "noesis" consciente; sino nuestro espíritu iluminante. De este foco, "faz interna",

59. De Trin. XII, 3, 3, PL. 42, 999

60. Non enim solum corpus homo exterior deputabitur; sed adjuncta quadam vita sua, qua compages corporis et omnes sensus vigent, quibus extructus est ad exteriora sentienda. (Ib. XII, 1, 1, PL. 42, 997). 
sale la luz que esclarece todas nuestras ideas y conceptos cognoscitivos, "faz externa".

No hemos de entender esto como si las ideas y conceptos estuvieran quién sabe dónde, esperando en la oscuridad la luz reveladora. Tampoco en ningún sentido innatista, como si salieran formados "a priori" del propio foco interior. Visión racional significa hacernos cargo del "ser" de los entes que entran de algún modo en el juego de nuestras interacciones. Nuestra visión racional surge en el encuentro de los entes que no somos nosotros, con el ente espiritual que somos nosotros. Para que este encuentro fuera perfecto, deberia ser de "faz interna" con "faz interna" directamente. En nuestro estado actual, no es ése el caso, ya que la acción de los entes exteriores sólo llega a la presencia de nuestro espiritu a través de los sentidos por caminos complicados. De todos modos, sólo hay visión o conocimiento cuando a consecuencia de una interacción más o menos perfecta del ser de algún ente externo, con el ser de la "faz interna" de nuestra alma racional, se hace visión la luz de nuestra mente. Sin esta concurrencia, la "faz externa" careceria de actividad y permanecería oscura.

Podemos, pues, acepiar que nuestra mente es "tanquam tabula rasa in qua nihil est depictum" antes de que haya recibido la primera impresión desde fuera por el camino de los sentidos; pero estamos muy lejos de admitir que sea un lienzo meramente pasivo, destinado únicamente a recibir escuetamente lo que los sentidos puedan pintar en él. En la interacción de que hablamos, los sentidos aportan su luz, y nuestra alma racional la suya. Ambas son necesarias para que surja el conocimiento de la verdad. Pero la luz de los sentidos es tenue y desvaída; en cambio la de nuestra "faz interna" es poderosa, y sólo en ella pueden esclarecerse los misterios del "ser" en grado suficiente para que nosotros podamos hacernos conscientes de ellos. Es claro que no se produce el resplandor del conocimiento en el contacto de cualesquiera entes. Para que éste brote, es preciso que la participación en el "ser" de que goza el cognoscente sea de más altos quilates que lo que observamos en los entes materiales sensibles. Además, y en todo caso, se necesita que la participación en el "ser" de ambos entes, el cognoscente y el conocido, sea de algún modo comunitaria. Tiene que ser la misma la fuente donde todos beben el "ser". Sin esta comunidad particionaria sería imposible inicialmente cualquier contacto interactivo; $y$, en consecuencia, toda acción de iluminante o iluminado.

En esto de la iluminación cognoscitiva debemos superar radicalmente la metáfora, no pensando que se trata de una iluminación a lo lejos y como por fuera de los entes que entran en juego; como parece suceder con la luz sensible. La iluminación cognoscitiva es siempre de ser a ser, y por el interior mismo de los seres. O sea, primero el ser, y después el conocimiento. La posibilidad de esta 
comunicación exige, decíamos, como base imprescindible alguna suerte de comunión mutua originaria en la raíz misma de su propio ser, que anteceda al ocasional encuentro cognoscitivo. Gracias a esta circunstancia, el ente cognoscente podrá ver en su propia luz al ente conocido en la medida que lo permitan, por un lado, la excelencia de su propio ser; $y$, por el otro, el modo del contacto ocasional con el ser conocido.

Podríamos decir que la excelencia ontológica de la "faz interna" del alma racional contiene con holgura virtualmente el ser de que gozan los entes sensibles; siendo esa la causa de que pueda hacer concordar la luz expresiva del conocimiento con la luz propia de la entidad que intuye, es decir, la que tiene presente en el contacto ocasional por intermedio de los sentidos. $\mathrm{Y}$ no lo ve sólo como caso concreto aislado, sino como modo general en que participan del ser todos los posibles casos semejantes. Y esa es la luz con que nuestra mente se apercibe de las "reglas del arte inefablemente be110" a que se ajustan los entes sensibles en sus operaciones, -leyes naturales-, o los ajustamos nosotros en nuestras obras artísticas. Este es el modo como se forman nuestros conceptos generales a partir de las sensaciones singulares de los sentidos.

Decimos, pues, que para que haya verdad en nuestras visiones cognoscitivas, es preciso que éstas surjan al contacto directo o indirecto de un ser con nuestro propio ser. Lo cual no implica que en nuestras operaciones mentales interiores, en las que no hay por lo regular contacto alguno de seres externos con nuestra mente, sino un barajar de nuestros propios productos mentales, (recuerdos, imaginaciones, conceptos...), no pueda aparecer verdad alguna. Muy al con urario.. En las operaciones de la "faz externa" de nuestro espíritu, está siempre presente, aunque encubierta, la "faz interna" que, en cuanto le corresponde, garantiza la verdad general de nuestras reflexiones en la medida que se ajusten a la lógica. $Y$ ¿por qué nuestra "faz interna" nos ofrece tales garantías? Por su contacto con el Ser que es la fuente de toda verdad. Nuestra alma hacia afuera, llega al cantacio de los seres corpóreos a través de los sentidos, para conocer verdades particulares; hacia adentro, está en contacto con su Creador y puede apercibirse de verdades eternas. Evidentemente, tales contactos no non simétricos ni homogéneos.

Ya sabemos qué significa su contacto con Dios. Es el acto creante, en el cual recibe el poder suficiente para distinguir las luces de la Creación: las razones generales que la presiden; las conveniencias y desconveniencias; el bien y el mal; las reglas del arte inefablemente hermoso. $Y$ porque el contacto interno no es de intuición, las verdades que nos pone delante son de carácter general y cubren todo el horizonte de nuestra "noesis". Ellas solas no determinan la existencia de un ente particular. Pero ¿podría ser esto motivo razonable para relegar su importancia tras las verdades particulares 
que nos entran por los sentidos, como nos aseguran los empiristas? Nada más injusto. Quien haya seguido nuestros razonamientos, puede darse exacta cuenta de que, sin esa luz que nos viene de dentro, el conocimiento de las cosas corpóreas que nos aportan los sentidos, no sobrepasarian al de cualquier bruto. Sólamente gracias a la luz que está encendida para nosotros en la "faz interna" del alma, nuestros conocimientos son racionales.

Ahora bien, ¿tenemos algún indicio que nos obligue a pensar que esa luz de la razón tiene su origen primero en la "faz interna" de nuestra alma? Porque en tal caso tendríamos que seguir los gustos kantianos, y ver en ella, nuestra razón, el tribunal supremo que ordena nuestros conceptos intelectuales $\mathrm{y}$, a través de los conceptos, todas las impresiones sensitivas que nos llegan en turbión desconcertado por los sentidos. Seria, además, la base originaria de los axiomas matemáticos $\mathrm{y}$, en fin, de todas las que llamamos ideas generales. Por supuesto, sin otro valor cognoscitivo que el que resulte de su aplicación a la experiencia empírica. Hay en esto una sutil contradicción que pasaremos de largo. Pero es necesario observar, que si nuestra razón tuviera ese poder originario, sería también preciso que fuese el origen primero de la naturaleza a la que impone el orden. Pero nuestra razón no es ordenadora, sino contempladora de la naturaleza; ni tampoco es el fundamento físico de los axiomas y verdades inconmutables, como hemos visto claramente siguiendo las enseñanzas de San Agustín; sino sólamente su conocedora.

$\mathrm{Y}$ ¿cómo es conocedora nuestra razón? ¿Cómo se mueve en la "faz externa" de nuestra alma esa actividad cognoscitiva de verdades particulares por un lado, y de normas eternas generales que no se refieren en concreto a ningún hecho empírico? La garantía fundamental para nosotros de todas nuestras verdades radica en la naturaleza de la "faz interna" de nuestra alma. Pero esto sólo quiere decir que tal garantía está asegurada gracias a los dones con que el Creador ha dotado a la que es su creatura. Evidentemente, si la naturaleza de nuestra alma no superara a la de los brutos, no habría para nosotros verdades inconmutables. La garantía de nuestra certeza de poseer la verdad reside en la constancia cierta del contacto adecuado de nuestra "faz interna" con el ser del ente conocido. En lo que se refiere al conocimiento de las cosas sensibles, el contacto aludido se realiza mediante la experiencia empírica bien hecha. En cuanto a las verdades eternas, ¿de qué contacto se trata? Porque no es la "faz interna" de nuestra alma el origen de los axiomas, leyes generales, principios filosóficos, conceptos genéricos "a priori", ni siquiera de las categorias más generales. No hay en absoluto en ella nada que se parezca a las llamadas ideas innatas. Pero sí tiene potencia suficiente para recibir todo eso y verlo. Lo recibe por su contacto con el Creador.

Aquí resalta todo el alcance del pasaje de la nota 55, donde 
San Agustín nos dice que la imagen de Dios que hay en nuestra alma es tan poderosa, que es capaz de adherirse a quien la hizo. Está claro que con tal adhesión no se quiere significar sólamente la mera dependencia de toda criatura respecto al Creador. Lo que se indica es una especial relación de la imagen como tal con Aquel cuya imagen es. ¿Podrían expresarse más bella y brillantemente las relaciones de nuestra alma con Dios, en orden al conocimiento de los seres, que llamándola imagen del que es el origen de todo ser? Ser imagen de Dios quiere decir que en ella como que se delinean y especifican de algún modo los rasgos del Ser de Dios. La luz de la Verdad de Dios está, pues, en el alma de algún modo, y si no puede decirse que esté en ella toda la luz de Dios, sí podemos y debemos cecir que toda la luz del alma le viene de Dios.

$\mathrm{Y}$ ¿cómo está en Dios la luz de las verdades que se especifican en relación con las diversas ciencias y los diversos modos de considerar las cosas? De eso no sabemos absolutamente nada. Sólo estamos seguros de que no están en El a la manera que las distinguimos separadas en nuestra "faz externa". Ni siquiera están así en nuestra "faz interna". Pero nos damos cuenta de que la Verdad de Dios se reparte y especifica, con "número, peso y medida" en los distintos seres que integran la Creación, y en las diversas normas que dirigen el orden de sus operaciones. Nuestra alma racional se hace consciente en esas verdades en la comunicación externa desde el alto sitial que ella ocupa con los seres creados por Dios. En el acto de esa comunicación (nótese que tal acto por necesidad pertenece a la "faz externa") surgen en ella resonancias de la Verdad Eterna "por la cual todas las cosas temporales fueron hechas", (v. 41), que acreditan sus títulos de "imagen de Dios".

Así sabemos en qué consiste la justicia, y qué es ser hombre justo, aunque nosotros no seamos justos. Nuestra "faz interna" no puede resonar sino a los acordes de la justicia, aun cuando la "faz externa" de nuestras operaciones se destemple y desordene en la injusticia.

Así recoge nuestra mente las verdades particulares por los sentidos, y las generales por sí misma, (41 y 42), ajustándose a las normas eternas, al vibrar en consonancia con ellas, que en eso consiste el "intuitus mentis rationales" (v. n. 51).

Así conoce las reglas que ordenan las cosas corporales, y las que dirigen al artista en su obra (n. 52).

Así, en fin, se hace consciente de las "razones incorpóreas y sempiternas" que tienen su fundamento inmutable por encima de nuestra naturaleza mudable, y de las que no tendría noticia si no tuviéramos alguna clase de unión con ellas (n. 59).

Vemos, pues, que en la doctrina de San Agustin se destacan estos tres puntos:

1. ${ }^{\circ}$ Existen verdades eternas, reglas inconmutablemente per- 
manentes, razones y proporciones del arte bellísima que brilla en el orden de todo cuanto existe.

2. Es imposible que tales normas, de suyo eternas, tengan su fundamento en la naturaleza de nuestra mente: "nisi supra mentem humanam essent, inconmutabiles profecto non essent".

3. Hay algo en nosotros que se comunica con el fundamento de tales reglas eternas: "His nisi subjungeretur aliquid nostrum, non secundum eas possemus judicare de corporibus".

A todo lo cual se da respuesta clara en nuestros presupuestos. La esencia o "faz interna" de nuestra alma, que está de continuo en las manos mismas del Creador, recibe de El su luz; esto es, una virtud operativa tal, que puede comunicarse con los fundamentos del "ser" de las cosas en orden a su conocimiento; luz eterna en El $\mathrm{y}$ que persiste inconmutable en la "faz interna" del alma, porque ésta es "lo que Dios hace", y nunca la debemos confundir con 10 que "hacemos nosotros", que es su "faz externa".

Hay, pues, en nosotros luces inconmutables, aunque no lo son por nosotros. $Y$ esto es así, porque nuestra alma racional es de tal naturaleza, la ha creado Dios de tal manera, que es capaz de vibrar en consonancia con la luz eterna haciéndose consciente de ella en alguna medida.

"Debemos creer que la naturaleza de la mente intelectual ha sido creada de tal modo, que unida a las cosas inteligibles según el orden natural dispuesto por el Creador, ve tales cosas en cierta luz incorpórea de su propia especie, al modo que los ojos carnales ven los cuerpos... Han sido creados capaces de semejante luz y en congruencia con ella" ${ }^{61 .}$

¿Cómo podríamos dar a este texto toda su fuerza mejor que considerando decididamente que aquella luz intelectual con la que raciocinamos nosotros según nuestra "faz externa", nos reluce justamente desde la "faz interna" de nuestra propia alma? Esa luz "sui generis incorporea", ya quiera entenderse esta frase en el sentido de que es del mismo linaje incorporeo que el del alma, como parece obvio, o simplemente como de una naturaleza especificamente suya, pero en todo caso, inmaterial y no increada, ¿puede entenderse siquiera de otro modo que considerándola como brotando de la esencia misma del alma en cuanto siendo creada y conservada por Dios en el modo y rango que El dispone? Ciertamente no es eterna porque salga del alma, sino porque allí la introduce Dios.

Conocemos, pues, gracias a la Verdad eterna, todo lo que conocemos y ordenamos rectamente, porque todas las cosas han si-

61. Credendum est mentis intellectualis ita conditam esse naturam, ut rejus intelligibilibus naturali ordine, disponente Conditore, subjuncta, sic ista videat in quadam luce sui generis incorporea, quemadmodum oculus carnis videt..., cujus lucis capax elque congruens est creatus. (Ib. XII, 15, 24, PL. 42, 1011). 
do hechas por Ella; y también en su luz adquirimos el conocimiento de la "formam secundum quam sumus" (v. n. 41). Me parace que la inteligencia correcta de este texto, perfectamente ajustada al pensamiento de San Agustín, se consigue, no pensando que vemos en la Verdad eterna la forma de nuestro ser, sino al revés: conocemos la forma según la cual somos, nuestra esencia, la "faz interna" de nuestra alma, porque en ella brilla para nosotros la luz eterna. Es imposible, en efecto, que veamos la luz eterna por fuera de nosotros. El camino de comunicación de la Verdad eterna con nosotros no puede ser distinto de su propia obra en nosotros: la "faz interna" de nuestra alma racional.

La Iuz del conocimiento arranca del "ser", y brilla como manifestación del ser en la región de la "noesis". Parecería que esta región luminosa está naturalmente arriba; mientras el ser se oculta en lo profundo. Pero esto no pasa de ser una imaginación ingenua, que puede ser engañosa y hasta perniciosa. La verdad es que la región de nuestros pensamientos y cavilaciones está integramente en la "faz externa" de nuestra alma racional, y le llega la luz desde su "faz interna", región serena puesta en las manos del Creador, y esa es para nosotros la región alta por donde nos llega la luz. Las mismas criaturas corpóreas son visibles al alma racional que contempla en ellas el orden y la belleza de sus "números", porque en la "faz interna" de sus esencias brilla la luz del "ser", luz del Creador; la cual, al propio tiempo que es propiedad privada, pues nada más propio de un ser que su propia entidad, es a la vez común, por cuanto es participación de la misma fuente.

Pueden comentarse en este sentido los pasajes aducidos arriba a propósito de la demostración de la existencia de Dios, en los que se destaca el hecho de que por encima de nuestras mentes hay una verdad inconmutable, que no es propiedad de ningún hombre y se muestra en común a todos, y es superior a nuestras mentes, (v. $n$. 36 y 37). Hay una verdad eterna que contiene todas las verdades inconmutables. Cuando San Agustín dice: "haec omnia quae inconmutabiliter vera sunt continentem", está pensando en las distintas verdades generales y axiomas que se enuncian en las diferentes ciencias humanas; todas las cuales deben estar contenidas, en última instancia, en la Verdad Eterna. Siguiendo la mente de San Agustín, esas verdades generales de las ciencias, visibles para nosotros, no están asi en la Verdad Eterna "ad intra", donde nosotros no podriamos verlas; sino "ad extra", o sea, en alguna cosa creada, en la que resplandece la luz originaria de tal manera oue sea visible para nosotros. $\mathrm{Y}$ esto en verdad de un modo maravilloso: "tanquam miris modis secretum et publicum lumen", dándose en común a todos los que son capaces de conocer verdades inconmutables. "Omnibus inconmutabilia vera cernentibus, praesto esse communiter".

Las verdades generales que nosotros conocemos y a las que alu- 
de San Agustín no existen por sí mismas, sino sólo en nosotros. Al decir esto no debemos quedarnos en su existencia lógica meramente gnoseológica, en esa región que pertenece toda entera a la "faz externa" de nuestra alma racional. Si pensamos que todo lo que hay en nuestras ideas se concluye en esa vertiente externa de nuestra razón, nos sucederá lo que ya indicamos arriba: nos engañaremos perniciosamente. Las ideas generales en cuanto son expresión de nuestro saber acerca de alguna cosa, deben arraigar hondamente en la "faz interna" de nuestra alma; sin cuya luz, luz de nuestro "ser" racional, nada veríamos. Y a través de ella, esas mismas ideas de nuestra "noesis" deben alcanzar de algún modo el "ser" mismo de las cosas conocidas.

Las verdades eternas, por tanto, que reflejan una luz permanente puesta a nuestra disposición en los modos maravillosos de nuestro conocimiento, está dentro de nosotros mismos; de un modo radical y estable, en la "faz interna" del alma; y de manera diversificada y cambiante, en la "faz externa". Sin olvidar que esta "faz externa", resultado de toda clase de interacciones con su contorno, está enriquecida con las luces que los otros entes reciben cada cual de la fuente común.

Por fin, a poco que reflexionemos sobre el funcionamiento de esa "faz externa", comprenderemos perfectamente la distinción que San Agustín quiere destacar cuando insiste en que una cosa son esas verdades particulares en que el hombre piensa ocasionalmente, y que son exclusivamente propias suyas, de modo que nadie tiene acceso a ellas si él no quiere manif̣estarlas, y aun entonces el otro sabrá de ellas por fe en la palabra, no porque las vea directamente; y otra cosa muy distinta son las reglas inconmutables que vemos en la verdad eterna, y que todos pueden ver igualmente, (v. n. 51). Lo que tratamos en la "faz externa" es nuestro; pero lo que vemos en la "faz interna", es común.

\section{LA "IMAGO DEI".}

La distinción de las dos "faces" en nuestra alma racional nos sirve admirablemente para esclarecer el camino que sigue San Agustín con el fin de perfilar lo más exactamente posible los rasgos con que aparece en el alma humana la "imagen de Dios", y precisamente en cuanto Dios es Trinidad. Para lograrlo le es preciso penetrar hasta lo más íntimo de la esencia del alma, y necesariamente tiene que encontrarse con su "faz interna". Trata de analizar el conocimieno que tiene el alma de sí misma; mas para que tal conocimiento le sirva para su objetivo, es decir, para que se dibuje en él la silueta de la imagen divina, tiene que purificarle de todo los que no sea ella misma; de suerte que al decir que se conoce a sí misma, no resulte eso que conoce ni inferior ni superior a ella. 
"Cuando la mente se conoce y aprueba a sí misma, de tal suerte es este conocimiento su propio "verbo", que resultan par a par exactamente iguales y constantemente los mismos" 62 .

El "verbum mentis" uno de los rasgos de la imagen divina en el alma, constituido por el conocimiento de sí misma, que busca en ella San Agustín, debe igualarla totalmente y sin interrupción. Para iograr distinguirle, es preciso eliminar mucho, por no decir todo el fárrago de los pensamientos de la "faz externa". Si, en efecto, nos encontramos de una vez exclusivamente en la "faz interna" del alma, las condiciones que San Agustín exige se cumplen perfectamente, y preparan el camino para lo que asienta poco después.

"De entrambos nace la noticia: del cognoscente y de lo conocido. Así que cuando la mente se conoce a sí misma, de ella sola brota a la luz el conocimiento: tanto el cognoscente como lo conocido, es ella misma" ${ }^{63}$.

En lo que debe aparecer la imagen divina, tiene que estar sola la mente, purificada de cualquier cosa extraña, siendo ella al mismo tiempo el cognoscente y lo conocido.

El cumplimiento de estas condiciones hace saltar al medio una no pequeña dificultad, pues ello exige que el alma se conozca de algún modo verdadero, entera y siempre, aun cuando no piensa en sí misma, y ni siquiera es capaz de enunciar ni explicar nada de sus propias cualidades. San Agustín plantea la dificultad al fin del libro IX de Trinitate:

"Ya era conocible para sí antes de conocerse; pero cuando no se conocía, no estaba en ella la noticia de sí misma" 64.

¿Cómo puede entenderse que la mente se conozca siempre a sí misma desde el primer momento de su existencia? Este es el problema que va a analizar en los libros siguientes. Una vez aclarado este hecho, quedará demostrado también que su conocimiento se iguala enteramente consigo misma:

"Lo que se conoce a sí mismo engendra un conocimiento de sí mismo igual a sí mismo" (ib.).

Emprende, pues, desde el principio del libro $\mathrm{X}$ un minucioso examen del conocimiento del alma, y comienza asentando como principio inconcuso, que nadie puede amar lo que absolutamente ignora:

62. Cum se mens ipsa novit atque approbat, sic est eadem notitia verbum ejus, ut ei sit par omnino et aequale, atque identidem. (Ib. IX, 11, 16, PL. 42, 970).

63. Ab utrodue notitia paritur, a cognoscente et cognito. Itaque mens cum se ipsam coanoscit, sola parens est notitiae suae: et cognitum et cognitor ipsa est. (Ib. IX, 12, 18, PL. 42, 970).

64. Erat sibi ipsa noscibilis, et antequam se nosset: sed notitia sui non erat in ea, cum se Ipsa non noverat. Quod ergo cognoscit se, parem sibi notitiam sui gignit. (Ib. IX, 12, 18, PL. $42,970)$. 
"Porque nadie puede amar en modo alguno una cosa desconocida totalmente". ${ }^{65}$.

Y llega a la cuestión central: ¿qué es lo que ama el alma cuando ardientemente desea conocerse?

"He ahí a la mente buscándose a sí misma para conocerse... Algo, por tanto ama; pero ¿qué cosa? ¿Tal vez a sí misma? Pero, ¿cómo, si aún no se conoce, y es imposible que nadie ame lo que ignora?... Por ventura ve en la razón de la verdad eterna cuán hermoso es conocerse a sí misma, y ama eso que ve y anhela que se realice en sí misma?" ${ }^{66}$.

Supongamos que no tiene el amor rastro de conocimiento de sí misma, y ve directamente en la Verdad eterna cuán hermoso es conocerse. Pero ¿no resulta esto contradictorio en sí mismo? ¿Cómo podría suceder que no conociéndose en modo alguno, conozca que es cosa bella el conocerse?

"Cosa en verdad sorprendente, no conocerse aún, y saber de antemano que es algo muy bello el conocerse" (ib.).

Por otra parte, sabe de su conocimiento de otras cosas distintas de ella; y ¿no se conoce a sí misma? Mas ¿cómo puede ser esto posible: tener conocimiento de su propio conocimiento, sin saber nada de sí misma?

"Sabe que conoce otras cosas, pero a si misma no se conoce... Pero ¿cómo puede ser que se conozca sabiendo algo la que nada sabe de sí misma? Porque no es otra mente de la que sabe que conoce, sino ella misma. Se conoce, pues, a sí misma. No es posible que se ignore la que al saberse ignorante, es ella misma la ignorante que conoce" 67 .

Está claro, por tanto, que si el alma conoce otras cosas, es preciso que se conozca a sí misma como condición previa, o al menos, concomitante.

Cuando nuestra mente revuelve dentro de sí misma las imágenes de los cuerpos, concurre para darles forma con algo de su propia substancia; pero mantiene como en reserva una parte de sí misma que sea a modo de árbitro y juez de las mismas.

"Se reserva algo desde donde pueda juzgar libremente

65. Quia rem prorsus incognitam amare omnino nullus potest. (Ib. $X, 1,1, P L .42,972$ ).

66. Ecce enim mens semetipsam quaerit noverit... Amat igitur: sed quid amat? Se ipsam? Quomodo cum nondum noverit, nec quisquam possit amare quod nescit?... An in ratione veritatis aeternae videt quam speciosum sit nosse semetipsam, et hoc amat quod videt, studetque in se fieri? Et hoc quidem permirabile, nondum se nosse, et quam pulchrum sit se nosse jam nosse. (1b. $X, 3,5$, PL. 42, 975).

67. Nam novit quod alia noverit, se autem non novit... Quo pacto igitur se scientem scit, quae se ipsam nescit? Neque enim alteram mentem scientem scit, sed se ipsam. Scit igitur se ipsam. Non potest omnino nescire se, quae dum se nescientem scit, se utique scit. (Ib. PL. 42, 976). 
sobre la hermosura de tales imágenes; y eso es justo la mente" 68 .

Si consideramos que la "faz interna" de nuestra alma racional, su propia esencia física, es el fundamento de la "faz externa", esto es, la base de la existencia de todo ese mundo de nuestros pensamientos y conocimientos actuales y pasajeros, comprendemos que ella es el principio desde donde se despliega todo el horizonte de nuestra "noesis", y como el juez de todos sus valores. Mas por otra parte, nos damos cuenta también de que, estando necesariamente en el centro mismo de nuestro pensar, no la tenemos ni podemos tenerla en el foco mismo de nuestra cogitativa, que de suyo pertenece a la "faz externa"; y por lo mismo, no tenemos conocimiento directo de nuestra "faz interna".

"Cuando se le manda que se conozca a sí misma, no ha de buscarse como si estuviera apartada de sí misma... Es ella interior, no sólo más que los cuerpos sensibles que tiene en su contorno..., sino más aún que las imágenes de los mismos que guardamos en alguna parte del alma" 69 .

Es, pues, la mente que busca San Agustín más interior que sus propias imaginaciones. Esto es, en efecto, lo que corresponde con toda propiedad a la "faz interna". Y por cuanto se necesita considerar en su máxima pureza esta zona más íntima del alma, es preciso separarla de todo lo que tiene en su "faz externa" y no es ella misma :

"No ha de ir a buscarse como a un ausente para verse; esfuércese, más bien, por distinguirse entre lo que tiene presente. No tiene que acercarse a sí como a cosa de que no sabe; sino dejar de sí lo que sabe que es otra cosa" ${ }^{70}$.

¿Cómo podrían cumplirse mejor estos consejos que distinguiendo las dos "faces" de nuestra alma racional? Pero no es fácil, al parecer, hacer correctamente semejante distinción.

"Aunque no siempre pensaba en si misma como sebarada de lo que no es ella misma; y por eso es difícil distinguir bien en ella la "memoria sui" y la "intelligentia sui" 71.

Cuando, en efecto, no se empieza distinguiendo como es debido las dos "faces", es muy difícil después discernir en el mundo fenoménico de nuestros pensamientos lo que pertenece a la esencia de nuestra alma de lo que no es exclusivamente suyo.

68. Servat aliquid quo libere de specie talium imaginum judicet, et hoc est magis mens. (Ib. X, 5, 7, PL. 42, 977).

69. Cum ei praecipitur ut se ipsam cognoscat, non se, tamquam sibi detracta sit, quaerat... Interior est enim ipsa, non solum quam ista sensibilia quae manifeste foris sunt sed etlam quam imagines eorum quae in parte quadam sunt animae. (Ib. $X, 8,11, P L$. 42, 979).

70. Non itaque velut absentem se quaerat cernere, sed presentem se curet discernere. Non se quasi non norit cognoscat, sed ab eo quod alterum novit dignoscat. (Ib. $X, 9,12, \mathrm{PL} .42,980$ ).

71. Quamvis non semper se cogitaret discretam ab eis quae non sunt quod ipsa est: ac per hoc difficile disnoscitur in ea memoria sui, et intelligentia sui. (Ib. $X, 12,19, P L .42,984$ ). 
La existencia de la "faz interna" y su naturaleza apoya perfectamente las ideas de San Agustín cuando para fijar los contornos netos de la "imago Dei", dice que en el análisis de la mente humana, no hay que separar en ella dos mentes, sino sólo distinguir los diversos oficios de una sola mente. Al buscar la imagen de la Trinidad del alma, "in tota quaerimus". De suerte que si ocasionalmente falta la acción destinada a las cosas temporales, sin embargo la mente permanece íntegra.

"Es preciso encontrar la trinidad en la naturaleza entera de la mente, de modo que aun faltando la acción de lo temporal..., hallemos la trinidad en una mente unitaria jamás dividida. $Y$ una vez hecha la separación, encontremos no sólo una trinidad, sino la 'imagen de Dios' en aquella parte que pertenece a la comtemplación de las cosas eternas; y en la otra destinada para la acción en las cosas temporales, aunque nueda hallarse en ella una trinidad, pero no la imagen de Dios" 72

San Agustín ha recorrido el mundo de nuestros conocimientos corrientes y sensibles, encontrando en ellos claros vestigios de la trinidad; pero para instalar firmente la "imago Dei" en el alma, necesita una región más estable, que se encuentra efectivamente en la "faz interna", esencia física del alma saliendo de las manos del Creador. ¿Quién duda que es ella toda entera y que no puede temer menoscabo alguno de las vicisitudes de su "faz externa"?

Establecido en firme que la imagen divina debe estar entera en el alma entera, San Agustín insiste en que es preciso prescindir de todo lo que en ella es transeúnte.

"No encontraremos lo que conviene llamar imagen de Dios en la posesión de la fe, visión $\mathrm{v}$ amor que no durarán siempre; sino en lo que siempre permanecerá" "73.

Lo que constituye la imagen de Dios en el alma "rationali sive intellectuali", tiene que ser algo permanente, "quae immortaliter immortalitati ejus est insita". $Y$ aun cuando la razón o el entendimiento parezcan en el hombre como actualmente dormidos, "nunc in ea sit sopitus", siempre es el alma racional humana, en posesión permanente de su conocimiento y amor .

"Por eso, si ha sido hecha imagen de Dios en aquello que la hace capaz de razón y entendimiento suficientes para entender y amar a Dios, está claro que desde el momento en que comenzó a existir esta tan grande y maravillosa criatura, que ya esté tan desvaída que apenas se la pueda reconocer, o sea

72. Sed in tota natura mentis ita trinitatem reperire opus est, ut si desif actio temporalium..., in una nusquam dispertita mente trinitas inveniatur: et facta jam ista distributione, in eo solo quod ad contemplationem pertinet aeternorum, non solum trinitas, sed etiam imago Dei: in hoc autem quod derivatum est in actione temporalium, etiam si trinitas possit, non tamen imago Doj possit inveniri. (Ib. XII, 4, 4, PL. 42, 1000).

73. Non igitur in fidei retentione, contemplatione, dilectione, quae non erit semper, sed in eo quod semper erit, invenienda est quam dici oporteat imaginem Dei. (Ib. XIV, 2, 4, PL. 42, 1038). 
borrosa y deformada, o transparente y hermosa, en todo caso esta imagen siempre subsiste" 74 .

Evidentemente, si consideramos la "faz interna" del alma racional, resulta diáfana y estable la imagen que Dios imprime en ella; y comprendemos que jamás podrán hacer peligrar su constancia los errores de nuestra "faz externa" por mucho que la ensucien y obnubilen.

La imagen de Dios en el alma debe, pues, ser permanente, esto es, debe comenzar a existir en el mismo instante de la creación del alma, continuar ininterrumpidamente durante toda la vida en este mundo y perseverar para siempre en la vida futura. Por otra parte, en esta imagen tienen que destacarse las tres notas que representan la Trinidad divina, como algo propio e inalienable de su naturaleza. Debe haber, pues, algo en el hombre de lo que pueda decirse con verdad en cualquier circunstancia de su vida que se conoce y ama. San Agustín observa que nada puede conocer mejor nuestra mente que lo que más se le aproxima:

\footnotetext{
"Nada conoce mejor la mente que lo que tiene cerca de sí; y nada más cerca de sí que ella misma" 75.
}

Esto parece irrecusable; sin embargo, ¿se puede decir que nuestra mente se conoce mejor a sí misma que al libro o al árbol que tenemos delante de los ojos? San Agustín no retrocede ante esta situación. Tampoco de lo que pueda pensarse acerca de lo que pasa en un niño recién nacido. "¿Qué diremos de la mente de un infante?". La experiencia en este caso, observa San Agustín, poco puede ayudarnos. No obstante, es muy plausible que se pueda decir del niño, no que sea incapaz de conocerse, sino que no puede pensar en si mismo. "No puede ignorarse; pero sí puede no pensarse". Sea de esto lo que fuere, añade, de lo que estamos seguros, y esto nos basta, es que cuando el hombre sea capaz de pensar algo con verdad acerca de la naturaleza de su propia alma, encontrará eso dentro de sí mismo

¿Podríamos, en efecto, saber algo acerca de cualquier cosa sin conocer lo que está dentro de nuestra mente, "siendo así que cuanto sabemos sólo por la mente lo sabemos?" ${ }^{76}$.

En toda esta vigorosa argumentación de San Agustín, a pesar de su fuerza, se echa de menos algo que podríamos llamar nitidez de enfoque. Vemos su verdad a modo de imagen no del todo clara,

\footnotetext{
74. Ac per hoc, si secundum hoc facta est ad imaginem Dei quod uti ratione atque intellectu ad intelligendum et conspiciendum Deum potest, profecto ab initio quo esse coepit ista tam magna et mira natura, sive ita obsoleta sit haec imago, ut pene nulla sit, sive obscura atque deformis, sive clara et pulchra sit, semper erit. (Ib. XIV, 4, 6, PL. 42, 1040).

75. Nihil enim tam novit mens, quam hoc quod sibi praesto est; nec menti magis quidquam praesto est quam ipsa sibi... Quid itaque dicendum est de infantis mente?... An... non ignorare se potest, sed cogitare se non potest? (lb. XIV, 5, 7, PL. 42, 1041).

76. Inveniet autem non quod nesciebat, sed unde non cogitabat. (Ib. XIV, 5, 8, PL. 42, 1041).
} 
con sus bordes un tanto inseguros. Y la causa de todo eso es indudablemente por no tener presente la distinción entre las dos "faces" de nuestra alma. Nuestro entendimiento y voluntad no sólo están en el alma: son nuestra alma racional de un modo radical y al propio tiempo activo; pero esta actividad en la raíz, se conforma en un plano superior al círculo en que se desenvuelve la actividad cogitativa y apetitiva de nuestra vida mental ordinaria. Son entendimiento y voluntad en acto; pero éste es el "acto" originario y esencial, que desde su plano "primario", posibilita los actos dispersos del plano "secundario" en que se agita nuestra vida. No deben, pues, confundirse en ningún caso.

San Agustín, en los esfuerzos que hace por clarificar su pensamiento en este asunto, parece no buscar otra cosa que esa región serena de la "faz interna"; pero no dio el último paso. No encuentra el modo de pasar de la "cogitatio" reflexiva de la "faz externa", a la luz sin cabrilleos del entendimiento que resplandece en la "faz interna".

\begin{abstract}
"Es tanto el vigor del pensamiento, ('cogitatio'), que ni la misma mente logra en cierto modo estar en su presencia, sino cuando piensa en sí misma..., de suerte que ni la mente misma con que pensamos todo cuanto pensamos, puede colocarse a su propia vista, si no es pensándose a sí misma. Mas cómo puede suceder que no esté a su vista cuando no reflexiona sobre sí misma, siendo asi que es imposible que exista sin sí misma como si ella fuera una cosa, y otra su propia presencia, no puedo entenderlo" "7.
\end{abstract}

Sin embargo, cuando se ha hecho expresamente la distinción entre las dos "faces" del alma, este problema se resuelve por si mismo. La "faz interna", esencia completa del alma, en la que brilla la luz del conocimiento radical y divinamente, puesto que la está poniendo Dios "en acto" con su "acción creadora", se distingue perfectamente de la "faz externa", vertiente exterior de sus propias acciones, que si son también conocimientos verdaderos, pensamientos, "cogitationes", lo son gracias a la luz que reciben desde dentro; pero son, por decirlo asi, de calidad inferior, están en un segundo plano. Si no se distinguen las dos "faces", no es posible diferenciar estos dos planos; y entonces, la "cogitatio reflexiva" nos deslumbra y como que quiere obligarnos a admitirla sin crítica como lo más alto de nuestra mente.

En la "faz interna" hay un conocimiento propio e íntimo que es de modo diferente del conocimiento reflexivo que se destaca en la

77. Tanta est tamen cogitationis vis, ut neque ipsa mens quodam modo se in conspectu suo ponat, nisi quando se cogitat...; ut nec ipsa mens qua cogitatur quidquid cogitatur, aliter possit esse in conspectu, nisi se ipsam cogitando. Quomodi autem, quando se non cogitat, in conspectu suo non sit cum sine se ipsa nunquam esse possit, quasi aliud sit ipsa, aliud conspectus ejus, invenire non possum. (Ib. XIV, 6, 8, PL. 42, 1041). 
"faz externa"; pero no inferior: muy al contrario, por cuanto es luz originaria, la misma que se refleja en los distintos conocimientos ocasionales nuestros, haciéndolos posibles. Es la misma que San Agustín pugna por sacar al medio cuando dice:

"Resulta, por tanto, que 'su presencia' es algo que pertenece a su naturaleza, y se voltea hacia ésta cuando piensa en sí misma, con una evolución no espacial, sino incorpórea; mas cuando no piensa en sí misma, no está por cierto a su vista, ni se informa de ella su mirada. Sin embargo, se conoce como siendo ella para sí misma la "memoria de si" 78 .

"Algo que pertenece a su naturaleza", esto es la "faz interna", "se voltea cuando piensa en sí misma", es decir, cuando reflexiona con los pensamientos de su "faz externa". "Sin embargo se conoce como siendo "memoria de sí". Este conocimiento está en un plano más alto, no es del mismo orden a que pertenecen las "cogitationes" anteriores.

La "faz interna" del alma racional se identifica con lo que San Agustín llama "memoria sui", cuando se la despeja de todo el fárrago de las acciones externas. Es una cierta forma de expresión metafórica, que explica a continuación diciendo que esto es así a la manera que con toda propiedad se dice que están en la memoria del perito los principios del arte que conoce; aun cuando no piensa en ellos por el momento. Lo cual no significa en modo alguno que San Agustín pensara que así como en la memoria del perito hay especies, digámoslo así, concretas y diferenciadas para su propio arte, de igual manera la "memoria sui" del alma racional humana contiene originariamente algo a modo de ideas innatas de cualquier género. Las ideas diferenciadas están todas en la "faz externa", y ni siquiera habla aouí San Agustín de ellas sino como término de comparación. Aquí se trata de la esencia misma del alma.

La "memoria sui", conocimiento interno de la "faz interna", pertenece a una esfera superior a la de todos los conocimientos particulares; particulares digo, no en referencia a su condición lógica, sino en cuanto son hechos psíquicos concretos. Es aquél un conocimiento de indole más alta, y oue constituye el fundamento de todos los demás conocimientos. La "memoria sui" y la memoria del sabio con respecto a las ciencias que posee, son de algún modo parecidas; pero nunca iguales.

"La mente, pues, cuando se mira al reflexionar, se entiende y reconoce, $\mathrm{y}$ no ciertamente como quien ve a un desconocido, pues se conocía ya, a la manera que conocemos lo que tenemos en nuestra memoria" ${ }^{79}$.

\footnotetext{
78. Proinde restat ut aliquid pertinens ad ejus naturam sit conspectus ejus, et in eam quando se cogitat, non quasi per loci spatium, sed incorporea conversione revocetur: cum vero non se cogitat, non sit quidem in conspectu suo, nec de illa suus formetur obtutus, sed tamen noverit se tanquam ipsa sit sibi memoria sui. (Ib. PL. 42 ,1042).

79. Mens igitur quando cogitatione se conspicit, intelligit se et recognoscit. Nec ita sane...
} 
$\mathrm{Y}$ eso desde el primer instante de su existencia; todo lo cual se comprende perfectamente desde la distinción de las dos "faces".

Quien la entienda bien no caerá en el error de pensar que con ella queremos establecer una especie de división en la mente, enérgicamente desechada por San Agustín, a fin de tener en la externa un punto de mira para contemplar la interna desde él, y viceversa, o cosa parecida. No hay nada de eso. La "memoria sui" no es un producto que la reflexión elabora para guardarla en su repostería. Por otra parte, cuando la mente reflexionando trata de conocerse a sí misma, nunca logra completarse directamente. Lo más que logra es un conocimiento indirecto, imperfecto e insuficiente para lo que pide San Agustín. Tampoco le es necesario.

Como decíamos, la "memoria sui" es un conocimiento de un orden más elevado que el de la "noesis" de nuestra "faz externa". Es el "orden primario" de nuestra inteligencia y voluntad, del que se deriva el "secundario" de nuestra "noesis" y de nuestra " moral práctica". Ese conocimiento primario que se identifica con la esencia de nuestra alma espiritual, no fracasa nunca desde el primer momento de nuestra existencia. Si no se tiene en cuenta estos dos órdenes de conocimiento, es imposible liberar de una cierta niebla molesta los muchos pasajes de San Agustín sobre este asunto, tan luminosos y convincentes por otra parte. Tenemos aquí algo semejante a lo encontrado en el análisis del ente material. La "fuerzaespacio-tiempo" de su sistema esencial originario constituyen un orden primario que es preciso distinguir de su correspondiente orden derivado secundario para comprender los misterios del espacio y del tiempo.

"Esto nos advierte que hay en nosotros en lo más escondido de nuestra mente la noticia de algunas cosas, (los principios del arte que se aprendió), que en cierto modo se nos ponen delante al pensar en ellas... Asi también encuentra nuestra mente que estaba en su memoria, se entendia y se amaba, aun sin pensar en ello cuando pensaba otras cosas" ${ }^{80}$.

Recuerda, entiende y ama aquello con que piensa en otras cosas sin pensar en sí misma. Recuerda, entiende y ama en su "faz interna" no como quien piensa en ideas preformadas, sino de un modo muy distinto: sin pensar ni reflexionar, (cogitare). Pero San Agustín no pensó nunca en discernir de un modo preciso las dos "faces". Por eso se ve obligado a añadir:

"Pero de qué depende que podamos pasar mucho tiempo

tanquam sibi ante incoanita fuerit: sed ita sibi nota erat, quemadmodum notae sunt res quae mểoria continentur. (Ib.)

80. Hinc admonemur et esse in nobis in abdito mentis quarumdam rerum quasdam notitias, et tunc quodam, modo procedere in medium... cuando cogitantur: tunc enim se ipsa mens, et méminisse, et intelligere, et amare invenit, etiam unde non cogitabat, quando aliud cogitabat.

Sed unde diu non cogitaverimus, et unde cogitari nisi commoniti non valemus, id nos nescio quo eodem miro modo, si potest dici, scire nescimus. (Ib. XIV, 7, 9, PL. 42, 1043). 
sin que pensemos en nosotros, y cómo sucede a veces que no somos capaces de hacerlo sin una llamada de atención, esto no sé de qué maravilloso modo, lo sabemos, si así puede decirse, ignorándolo" (ib.).

Esta es también la causa de que sea obligado a explicar minuciosamente en qué consiste y cómo engendra el "verbo de la mente", para que se entienda que la imagen de la trinidad no está exclusivamente en la memoria, como pudiera pensar alguien que no comprendiera bien aquel calificativo de "memoria sui" con el que quiere designar la parte interior del alma.

"Porque si nos referimos a la memoria interior de la mente con la que se acuerda de sí, y a la inteligencia interior con la que se entiende, $\mathrm{y}$ a la voluntad interior con la que se ama, y consideramos dónde están las tres siempre, y siempre estuvieron juntas desde que empezaron a existir, ya se pensase en ellas o no, parecería que la imagen de aquella trinidad pertenecia exclusivamente a la memoria; mas, puesto que el "verbo" no puede estar allí sin el pensamiento (sine cogitatione)..., reconocemos dicha imagen en las tres, a saber: memoria, entendimiento y voluntad" ${ }^{81}$.

$\mathrm{Y}$ el problema consiste ahora en introducir en la "memoria sui", o "faz interna" del alma, esa "cogitatio" necesaria para engendrar el verbo, y que es fruto exclusivo de la "faz externa". Por lo pronto, es necesario retener que la memoria, inteligencia $\mathrm{y}$ voluntad, rasgos de la imagen divina, son inalienables del alma.

"En nuestro análisis llegamos ya a aquella parte principal de la mente humana, mediante la cual conoce a Dios... en la que debe encontrarse la "imagen de Dios"..., Tenemos que buscarla y encontrarla en lo que tiene de mejor nuestra naturaleza. Pero debe ser considerada la mente en si misma, aun antes de que llegue al goce de Dios, y en ella debe encontrarse la imagen de Dios. Pues como ya dijimos, aunque al perder la gracia de Dios haya quedado desvaída y deformada, permanece, sin embargo siendo "imagen de Dios" 82 .

Cuando San Agustín nos dice que debemos buscar la imagen divina en lo que nuestra naturaleza tiene de más excelente, vemos una vez más que está pensando en algo que concuerda perfectamente con lo que nosotros llamamos "faz interna" del alma racional. Insiste incansablemente en considerarla limpia de toda impureza exterior:

81. Nam si nos referamus ad interiorem mentis memoriam qua sui meminit, et Interiorem intelligentiam qua se intelligit, et interiorem voluntatem qua se diligit, ubi haec tria semper sunt, et semper simul fuerunt ex quo esse coeperunt, sive cogitarentur, sive non cogitarentur; videbltur quidem imago illius trinitatis et ad solam memoriam pertinere, sed quia ibi verbum esse sine cogitatione non potest... in tribus... imago ista cognoscitur, memoria scilicet, intelligentia et voluntate. (Ib. XIV, 7, 10. PL. 42, 1043-1044).

82. Ad eam jam pervenimus disputationem, ubi principalis mentis humanae, quo novit Deum..., considerandum suscepimus, ut in eo reperiamus imaginem Dei... Ibi quaerenda et invenienda' est in nojis, quo etiam natura nostra nihil habet melius. Sed prius mens in se ipsa consideranda est antequam sit particeps Dei, et in ea reperienda est imago ejus. Dlximus enim eam etsi amissa Dei participatione obsoletam atque deformem, Dei tamen imaginem permanere. (Ib. XIV, 8, 11. PL. 42, 1044). 
"He aquí, pues, que la mente se recuerda, se entiende y se ama: si comprendemos bien esto, vemos en ello la trinidad... imagen de Dios. Porque no recibió la memoria desde fuera lo que había de contener, ni el entendimiento encontró fuera lo que había de ver, ni la voluntad unió fuera ambas cosas" ${ }^{83}$ "Ni es ella advenediza para sí misma...; siendo asi que desde que comenzó a existir jamás dejó de recordarse, de entenderse y de amarse" ${ }^{84}$.

En definitiva, la imagen divina que Dios puso en nosotros, está, o mejor dicho, constituye la "faz interna", que, como tantas veces hemos repetido, es justamente la "acción" de Dios mediante la cual crea y conserva al alma racional. Esa "faz interna" nunca sufre menoscabo en sí misma, por cuanto es "acción" de Dios. Pero como de ella proceden sus propias "acciones", acciones por tanto de la criatura, éstas son las que en su "faz externa" la ensombrecen, decoloran, deforman y ensucian.

Naturalmente, esa "faz interna", "acción" divina, es el paso obligado de nuestra comunicación con Dios. San Agustín nos lo recuerda a propósito de la frase paulina: "videmus nunc per specuIum in aenigmate". $\mathrm{Y}$ a vueltas de la palabra enigma usada por San Pablo, se sumerge en nuevas cavilaciones ante la "imagen" que de suyo deberia ser menos confusa.

"Este es el mayor enigma: no ver lo que no podemos menos de ver. Pues ¿quién no ve su propio pensamiento? y ¿quién ve su pensamiento?" 85

Todos, en efecto, se dan cuenta de lo que están pensando, esto es, ven sus pensamientos como de frente; pero nadie puede ver de frente con su pensamiento pasajero, acción transeúnte propia de la "faz externa" de su alma, aquella "faz interna" que constituye el pensamiento originario, condición necesaria de todos los demás pensamientos. Esta "faz interna" no está, repito, en el foco de nuestros pensamientos corrientes, y tal como vivimos en esta vida, nos es imposible contemplarla en visión directa. Me refiero naturalmente a la visión racional, no precisamente a la sensible. Sin embargo, aunque no podemos ver cara a cara mediante nuestra "acción" reflexiva la "acción" de Dios en nosotros, sí la vemos indirectamente, y aparte de eso, de una manera especial y superior. Tenemos que verla necesariamente, puesto que es la luz oue ilumina todas nuestras visiones intelectuales. Esa luz corresponde al "verbum a Deo factae imaginis", al "verbo" de la imagen de Dios creada, que dice San Agustín:

83. Ecce, ergo, mens meminit sui, intelligit se, diligit se: hoc si cernimus, cernimus trinitatem... imaginem Dei. Non forinsecus accepit memoria quod teneret, nec foris invenit quod aspiceret intelfectus..., nec ista duo... voluntas foris junxit. (lb. PL. 42, 1045).

84. Neque adventitia sibi ipsa est...; cum profecto ex quo esse coepit, nunquam sui meminisse, nunquam se intelligere, nunquam se amare destiterit. (Ib. XIV, 10, 13, PL. 42, 1047 ).

85. Et hoc est grandius aenigma, ut non videamus nuod nnn videre non possumus. Quis enim non videt cogitationem suam? et quis videt cogitationem suam? 
"Debemos llegar al "verbo" del hombre, al "verbo" de la imagen de Dios hecha por Dios; que no es prolativo... ni cogitativo...; sino que precede a toda clase de signos con los que es significado, y se engendra del conosimiento que permanece en el alma, al ser enunciado interiormente tal cual es" ${ }^{86}$.

Este es el verbo interior que precede "a todos los signos con los que se le expresa exteriormente". Y al modo que del Verbo de Dios representado en este verbo humano, se dice que todas las cosas fueron hechas por El, asimismo:

"No hay obra alguna en el hombre que no sea enunciada de antemano en su corazón" 87.

La luz que ilumina todos nuestros pensamientos y disposiciones con que gorbernamos nuestra vida, procede de ese foco íntimo, que es la "faz interna" de nuestra alma racional.

Pero aun persisten algunas sombras que impiden una clarificación definitiva. En primer lugar, ese verbo interior de nuestra mente, ¿será algo que pertenece a nuestra propia substancia? Podemos decir perfectamente que nuestro verbo es la visión de nuestra visión, la ciencia de nuestra ciencia. Pero ¿se podrá decir también de él que es la esencia de nuestra esencia?

"¿Por ventura... puede llamarse asimismo esencia de la esencia?... Y ¿cómo asi? Porque no es lo mismo para nosotros el ser que el conocer. Ya que conocemos muchas cosas que viven de algún modo por la memoria, y de la misma manera mueren por el olvido...; y al propio tiempo que perece nuestra ciencia cuando se nos va, nosotros, no obstante, vivimos" 88 .

¿Cómo podríamos pensar que nuestro verbo interior pertenece a nuestra esencia, si es tan evidente la diferencia entre nuestro ser y nuestro conocer? Otra vez el entrecruzamiento de las dos "faces" del alma viene a perturbar el desarrollo normal del pensamiento de San Agustín. Sin embargo, se defiende contra viento y marea, y aduce una zona de nuestro pensamiento que no está sujeta al vaivén de la vida exterior. Ciertamente no la presenta aún con la seguridad del que ha conseguido la victoria definitiva. Dice así:

"Aun las cosas que de tal modo son conocidas que nunca se nos pueden ir, porque su presencia pertenece a la misma naturaleza del alma, como es nuestro conocimiento de que vivimos: permanecerá esto siempre mientras permanezca el al-

86. Perveniendum est ergo ad illum verbum hominis, ad verbum... a Deo factae imaginis Dei, quod neque prolativum est..., neque cogitativum...; sed quod omnia quibus significatur sig. na praecedit, et gignitur de scientia quae manet in animo, quando eadem scientia intus dicitur sicuti est. (Ib. XV, 11, 20, PL. 42, 1072).

87. Ita hominis opera nulla sunt, quae non prius dicatur in corde. (Ib.)

88. Nunquid ita dici potest essentia de essentia?... Quid ita? Quia non hoc est nobis esse, quod est nosse. Multa quippe novimus quae per memoriam quodam modo vivunt, ita et oblivione... moriuntur...; et cum scientia nostra animo lapsa perierit a nobis, nos tamen vivimus. (Ib. $X V, 15,24$, PL. 42, 1078). 
ma, y como el alma permanece siempre, siempre permanecerá. Esto, pues, y... otras cosas semejantes, en las que principalmente debemos ver la imagen de Dios, aunque siempre conocidas, sin embargo, puesto que no siempre se piensa en ellas (cogitantur), es muy difícil comprender cómo puede enunciarse en ellas un verbo sempiterno; siendo así que nuestro verbo se enuncia en nuestro pensar" (cogitatio)" ${ }^{89}$.

Mientras se piense que el "verbum mentis", rasgo necesario de la imagen divina permanente en el alma, debe ser engendrado por una reflexión cogitativa de la "faz externa" necesariamente transeúnte, es imposible enfocar nítidamente dicha imagen. Sempiterno es el vivir del alma y sempiterna su ciencia; pero pensar en su vida o en su ciencia, ¿cómo podría hacerlo nuestra mente sin interrupción? Sin embargo, así tendría que ser, porque "verbum verum nostrum intimum, nisi nostra cogitatione non dicitur". A no ser que sea suficiente la mera posibilidad de pensarlo:

"A no ser tal vez que deba decirse que la posibilidad misma de pensarlo (cogitationis)..., sea verbo tan perpetuo como es perpetua la ciencia misma" ${ }^{90}$.

Pero un verbo que todavía no ha recibido su forma en la visión del pensamiento... (ib). Decididamente, en la vida futura veremos con más claridad la Trinidad divina, que ahora vemos en nosotros su imagen:

"La veremos con más claridad y certeza que las que tenemos ahora en el conocimiento de su imagen, que somos nosotros" gl.

Pero en resumidas cuentas, desn due llamamos "verbum mentis" y que desempeña el oficio de imagen de Dios en el alma, ¿no tiene que ser en definitiva, algo substancial y no mero accidente?

"Pero ¿qué es eso que puede llegar a ser verbo y por lo mismo ya digno de tal nombre? ¿Qué es, repito, eso formable, pero aún no formado, sino una parte de nuestra mente que sacudimos de acá para allá, con un a modo de movimiento volteante, cuando pensamos en éstas o las otras cosas?" ${ }^{92}$.

89. Illa etiam quae ita sciuntur, ut nunquam excidere possint, quoniam praesentia sunt, et ad ipsius animi naturam pertinent, ut est illud quod nos vivere scimus: manet enim hoc quamdiu animus manet, et quia semper manet animus, et hoc semper manet: id ergo et... similia, in quibus imago Dei potius intuenda est, etsi semper sciuntur, tamen quia non semper etiam cogitantur, quomodo de his dicatur verbum sempiternum, cum verbum nostrum nostra cogitatione dicatur, invenire difficile est. (Ib. XV, 15, 25, PL. 42, 1078).

90. Nisi forte dicendum est, osam possibilitatem cogitationis...; verbum esse tam perpetuum quam scientia ipsa perpetua est. (Ib.)

91. Multo clarius certiusque videbimus, quam nunc ejus imaginem quod nos sumus. (Ib. XV, 23. 44, PL. 42, 1091).

92: Sed quid est hoc quod potest esse verbum, et ideo jam dignum est verbi nomine? Quid est, inquam, hoc formabile nondum formatum, nisi quiddam mentis nostrae, quod hac atque hac volubili quadam motione jactamus, cum a nobis nunc hoc, nunc illud... cogitatur? (Ib. XV, 15 25. RL. 42, 1078). 
Es, en efecto, aquello íntimo en que consiste nuestro espíritu, que es una esencia física racional, constituida en fuerza o virtud que se ejerce en inteligencia cognoscente y en voluntad autodirectiva. No es, por cierto, algo que esté a merced de la volubilidad y capricho de los que parecen desgcbernados y sueltos pensamientos; sino todo lo contrario. Es un faro sereno del que nuestros pensamientos reciben su luz cognoscitiva, y nuestros apetitos las normas del bien obrar. Es, en fin, la "faz interna" de nuestra alma racional, de la que proceden todas las acciones de la "faz externa". Fuerza vital, no amorfa y sin rostro; sino hecha para actuar a su imagen y semejanza; y de este modo en su ser y en su obrar traza los rasgos de Aquél que la creó a su imagen y semejanza.

El entender y querer de nuestra "faz interna" dominan desde un plano superior al entender y querer de nuestra "faz externa". Estos no son otra cosa que el ejercicio concreto de nuestra subjetividad, y todo cuanto es objeto de esta actividad subjetiva externa, puede ser ulterior objeto de nuestra reflexión cogitativa. Pero la "faz interna" es tan sólo acción subjetivante y no puede ser objeto directo de nuestros pensamientos reflexivos. No obstante, no puede por menos de ser conocida nuestra, puesto gue es nuestro conocimiento mismo. Este pensamiento vibra por doquier en la exposición agustiniana de su doctrina gnoseológica.

Hay, pues, en nosotros dos vertientes bien diferenciadas, pero no escindidas: el sujeto, fuente de todo pensar y querer nuestro, "faz interna" de nuestra alma racional, su esencia espiritual física; y el mundo de nuestra actividad reflexiva y consciente: la "faz externa". Nuestra "faz interna" es una "actividad originaria", que, por un lado y como "acción", no es nuestra, sino del creador; mas por otro, es lo más nuestro que tenemos, puesto que es nuestro propio yo; el cual, a su vez, goza de su propia actividad derivada hacia sus afueras. Ambas actividades, originaria y derivada, obran en distinto plano, como repetidas veces hemos dicho, pero no están incomunicadas. Ciertamente, la actividad derivada no puede alcanzar de lleno a la actividad esenciante originaria. Nuestro yo se tiene a sí mismo en una noticia diferenciada y clara. Tal noticia tendría que ser "acción suya", y para lograrla, sería preciso abarcar la "actividad originaria" con la "actividad derivada"; lo que ya se ve que es imposible.

Sin embargo, es también necesario que cuando pensamos conscientemente veamos también de alguna manera lo que es la luz misma de nuestros pensamientos. Nuestro insigne agustinólogo Santiago de Viterbo veía esto claramente cuando escribió:

"Su conocer de otras cosas le guía al conocimiento de su propio acto al darse cuenta de que conoce aquello. Mas el conocimiento de su acto la lleva al conocimiento de que "es", conocimiento indiferenciado e imperfecto. "En el estado de 
esta vida no puede alcanzar el pleno conocimiento (de sí misma") ${ }^{93}$.

Mientras permanezcamos en las condiciones de esta vida, el conocimiento reflexivo de nuestro propio yo "físico" no puede ser sino imperfecto e indistinto. Pero no es un capricho fútil hablar de otra forma de conocimiento nuestro, que está en un plano superior al conocimiento reflexivo, y que brilla en el contacto de ser a ser de nuestra "faz interna" con los seres externos. Naturalmente, el fulgor de semejante contacto es cognoscitivo para nosotros gracias a la excelente calidad de nuestra "faz interna". Sólo por eso es "verdadeante" como diria Zubiri.

Quizá no sería impropio si dijéramos que esta actividad inteligente de la "faz interna" de nuestra alma racional es "comprensión preontológica del ser". Esta frase cierra el primer capítulo de la "Introducción" a la obra de M. Heidegger "El Ser y el Tiempo". Podría concordar, según creo, nuestra idea con el pensamiento general de ese capítulo, si no fuera por la intención decidida de Heidegger de prescindir del cimiento firme de la esencia, y asentar sus bases sobre la movilidad de la existencia. Nos dice en la pág. 17: "Este directivo echar una mirada al ser brota de la comprensión "de término medio" del ser en que nos movemos ya siempre, y que a la postre es inherente a la constitución esencial del "ser ahi" mismo" ${ }^{94}$. Las palabras subrayadas lo han sido por el autor; pero es seguro que él no les da la significación que de suyo tienen para nosotros. La "constitución esencial del "ser ahí", esto es, del hombre, es para nosotros la "faz interna" del alma racional humana, y justamente desde ella parte toda posibilidad de apertura "ontológica"; o sea, de la manifestación del ser para nosotros, esto es, del conocimiento de otros seres, gracias a su excelente constitución óntica esencial. Si llamamos "ontológico" el conocimiento reflexivo de los entes, ya que en él se nos manifiestan, debemos llamar al ser óntico del alma racional "ser preontológico", puesto que es preparación y presupuesto necesario de todo conocimiento. Dice Heidegger en la $\mathrm{p}$. 22: "Si reservamos el título de ontología para el preguntar en forma explícitamente teorética por el sentido de los entes, hay que designar este "ser ontológico" del "ser ahi" como "preontológico". En todo esto nos parece estar de acuerdo con él. También afirmamos que la "faz interna" del alma no está a disposición directa de nuestro conocimiento reflexivo, y podríamos, por tanto, subscribir las palabras de Heidegger cuando dice: "la definición de la esencia de este

93. Per aliquod aliud ab ipsa cognitum ducitur in cognitionem sui actus, cum percipit so cognoscere illud. Per cognitionem vero actus, ducitur in cognitionem quia est, quae est cognitio indistincta et imperfecta. In statu autem hujus vitae non potest ad plenum assequi hanc cognitionem. (Santiago de Viterbo. Primer Quodlibeto. Tomamos estas referencias de las notas aducidas por el P. Fidel Casado en la Rev. "Estudio Agustiniano". Vol. IV; Fasc. III. Año 1969).

94. Martĺn HEIDEGGER, El Ser y el Tiempo. Trad. de José Gaos. 2.a Ed. 
ente no puede darse indicando un "qué" de contenido material" (ib). Esto significa para nosotros que la esencia física de nuestra alma racional no puede ser representada exhaustivamente en ningún concepto intelectual nuestro.

Pero en lo que no podemos estar de acuerdo en modo alguno es en las consecuencias que deduce de este hecho. Dice, en efecto, "que su esencia reside en que no puede menos de ser en cada caso su ser como ser suyo" (ib). Estas palabras nos dicen, traducidas a nuestro modo de hablar, que la esencia del alma consiste en su "faz externa". Naturalmente siendo la cosa así "el ser mismo relativamente al cual puede conducirse y se conduce siempre de alguna manera el hombre tiene que llamarse "existencia" (ib). Y la mejor denominación para el hombre mismo será el "ser ahí; esto es, el ente que aparece debatiéndose entre el fárrago movedizo de circunstancias sin cuento.

Esto quiere decir, según Heidegger, que puesto que no podemos esclarecer a satisfacción el fundamento mismo de nuestros conocimientos, debemos prescindir radicalmente de él. No que volvamos cuidadosamente nuestra mirada analizadora a los conocimientos que tenemos de hecho y se nos muestran claramente en nuestra experiencia, para tratar, siguiéndoles el hilo, de ver en algún modo el fondo interior de donde salen, y así conocer de alguna manera nuestra esencia íntima. Se nos asegura que no hay tal esencia interior, y que la única esencia del alma, si esencia puede llamarse, es tan sólo lo aue venimos designando como nuestra "faz externa", el conjunto de todas nuestras acciones humanas, las cuales, según Heidegger, forman una totalidad perfectamente originaria.

Decididamente estamos en oposición completa con este modo de considerar las cosas. Es cierto que tenemos a nuestra disposición la "faz externa", en la que poseemos conscientemente nuestro propio ser; pero, si negando la otra "faz", afirmamos además que ella es el único fundamento de nuestro ser, 10 desquiciamos todo, y quedan rotos los hilos que podrían comunicarnos con la verdad. No habrá ya verdad para nosotros.

Pero la realidad es muy diferente. Nosotros gozamos del mundo de nuestros conocimientos precisamente porque en el fondo de nuestro ser hay una esencia que irradia luz racional capaz de producir nuestra "noesis", o visión de ser. Desde la cumbre de nuestra mente, linea divisoria entre las vertientes de ambas "faces", nuestra mirada racional, "conspectus mentis", rastrea los caminos de la verdad con luz que le viene por dentro desde arriba y sale hacia fuera al encuentro de las luces de los seres. San Agustín hizo como nadie el análisis de estos hechos, y llegó a la conclusión de que no puede haber más que un solo foco originario desde donde irradian todas las verdades, y que es "la Verdad", justamente por ser la fuente única de todo ser y de todo conocer. Si nosotros conocemos de 
hecho verdades eternas, es porque nos llega la luz suficiente desde el foco originario. Instalados en nuestro punto de vista, nos damos cuenta de cómo se realiza este milagro: es que el Creador grabó su imagen divina en nuestra alma racional.

\section{RECAPITULACION.}

Echando una mirada retrospectiva sobre el camino andado, podremos ver ahora con mayor claridad oue antes la solidez de la argumentación agustiniana filosófica sobre la inmortalidad del alma y la existencia de Dios. Ambas demostraciones se complementan conjugándose armónicamente en un sólo razonamiento.

San Agustín arguye la inmortalidad del alma por el hecho de que es capaz de contener en sí misma verdades evidentemente imperecederas. Pero al mismo tiempo comprende que sus razones se debilitan al comprobar la mutabilidad del alma, que se hace visible en los numerosos cambios experimentados por el hombre precisamente en lo que tiene de más noble: unas veces sabe, otras ignora; aprende y olvida; duda, yerra, etc. No aparece clara la posible inmortalidad de aquello que tanto muda.

Pero esta dificultad se desvanece cuando comprobamos que no deben confundirse las dos "faces" del alma; y que en nada se turba la serenidad de la "faz interna" por mucho oue varien las oneraciones de sus afueras, que constituyen su "faz externa". En esas operaciones de la "faz externa", que son obras nuestras y están a nuestra disposición, podemos destacar dos cosas: 1." Que hay entre ellas raciocinios en los que brillan nara nosotros con toda claridad verdades perennes, no suietas al tiembo. 2. ${ }^{2}$ Que todas esas obras nuestras, labor psicológica del momento, cambian con gran rapidez.

La primera demuestra la inmortalidad del alma. y la segunda nos indica, sin lugar a dudas, la existencia de Dios. En efecto, para que el alma sea capaz de cantar verdades inmortales, tiene oue ser ella inmortal. Pero como tales verdades no sólo son inmortales, sino eternas, esto es, libres totalmente del tiempo, es preciso que exista para ellas un sustentáculo adecuado, es decir, un ser estrictamente eterno. Los dos argumentos, oue al considerarlos algo confundidos, perturban el razonamiento agustiniano, una vez separados debidamente, le aclaran y fortifican.

Vavamos por partes. Nuestra intelección de verdades eternas indica claramente que nuestra alma está hecha nara no perecer jamás. Al decir "está hecha para", queremos significar oue la inmortalidad del alma es uno de los dones incluidos en su esencia. La tiene según su esencia; pero no en virtud de su propia esencia, ya que ella es toda entera donación del Creador. 
Comparemos la esencia espiritual del alma con la del ente material. El ente material es una fuerza mecánica que se desarrolla en espacio y tiempo. Su ser es un constante hacerse. Es verdad que resulta indestructible frente a cualquier fuerza creada que quisiera oponérsele; pero considerado en si mismo, parece que está hecho para que en cualquier momento acabe su desarrollo, llegando a su fin en la existencia. Es un flujo temporal que por su mismo modo de ser, se le ve que va buscando un término.

La esencia del espíritu humano no es así. Sus obras saltan por encima de los moldes tempóreos y piden eternidad. La extratemporalidad de los principios verdaderos científicos y filosóficos exigen que la esencia capaz de concebirlos, sea también de algún modo extra tempórea.

Tenemos que aclarar algunas cosas para evitar peligrosos equívocos. Las verdades generales aue hay en el alma racional son verdades lógicas meramente gnoseológicas; y parece, por tanto, que su extratemporalidad y carácter eterno poco tiene que ver con la posible eternidad física del alma. En efecto, no se puede confundir el valor lógico de un concepto, que bien puede ser gnoseológicamente inmutable, con las condiciones de su fundamento psíquico vital, que puede ser pasajero, y de hecho lo es sin duda en aquello que corresponde a las acciones de la "faz externa" del alma racional humana. Separemos, pues, cuidadosamente la inmutabilidad lógica de la mutabilidad psíquica de nuestro acto mental. Con ello queremos dejar bien claro que no se trata de argüir la inmortalidad del alma como consecuencia de una supuesta equiparación de términos. La verdad gnoseológica aue por ventura hubiere en el alma, no es equiparable con la esencia óntica del alma. Pero si es cierto que no hay entre ellas la relación de igualdad, no por eso debe negárseles toda clase de relaciones. Evidentemente hay una relación de causa a efecto entre el alma racional y sus conceptos lógicos. Ya hemos señalado repetidas veces que los actos psíquicos mediante los cuales elabora el alma sus conceptos lógicos de verdades eternas, son transeuntes y pertenecen todos a su "faz externa", con la cual concurren incluso elementos que están fuera de lo que propiamente le pertenece. Por consiguiente, la deleznabilidad de tales actos no arguye que la "faz interna" sea también deleznable.

Debemos, pues, comparar directamente la calidad eterna que brilla en nuestros conceptos lógicos, con la esencia física de nuestra alma racional, su "faz interna", no a título de igualdad, puesto que "noesis" y "fisis" no son la misma cosa; sino teniendo en cuenta que el conocimiento racional es un efecto inmediato que brota de la esencia y se sustenta en ella; y no sólo como acción psíquica, sino muy precisamente como valor lógico racional.

El ente material concurre consigo mismo y entra como parte 
integrante en algunas de sus acciones externas. Así tiene que hacerlo en virtud de su propia esencia física. Es, en efecto, "materia". Pero el ente espiritual es muy diferente. La esencia física de nuestra alma racional es causa eficiente de las verdades lógicas que brillan en nuestra mente; pero no es parte constitutiva de las mismas. Ya lo hemos recalcado muchas veces: "noesis" y "fisis" no pueden confundirse nunca en el mismo horizonte. Son realidades que están en planos diferentes. Pero la "noesis" no puede desprenderse de la "fisis" correspondiente. Tenemos dentro de nosotros un mundo espiritual poblado de innumerables entidades: imágenes, recuerdos, conceptos, ideas en general. Todas ellas son creaturas de la "faz interna" de nuestra alma racional y constituyen su "faz externa", producidas algunas con el concurso material de los sentidos. Ninguna se confunde con su esencia y todas penden de ella en su existir. Todo esto es un reflejo de la imagen de Dios que es nuestra alma. Dios creó las cosas conociéndolas; "ideo sunt quia novit" 95. Sólo que Dios, al conocer sus creaturas amándolas, constituyó sus correspondientes esencias físicas fuera de su propia Esencia. El alma racional no es capaz de infundir dureza existencial independiente a sus creaturas gnoseológicas, que sólo brillan cuando en ellas piensa.

Aquí se nos muestra la fuerza poderosa de la intuición agustiniana, y quizá también sus perplejidades. Ese mundo espiritual de nuestra alma con fulgores eternos, y que no obstante su evidente constancia en la verdad, aparecen y desaparecen, se encienden y se apagan, a veces son claros, otras oscuros en esa vertiente externa de nuestra alma, tienen que estar en alguna parte permanentes de alguna manera; y eso, a disposición de nuestra alma, para que pueda volverlos a ver o recordarlos a voluntad. Eso es justamente la "memoria sui", y bien pudiera ser ésta una definición de la esencia física de nuestra alma racional.

Pero es necesario considerar esta "memoria sui" o "faz interna", como desde dentro hacia afuera; porque algunos, por mirarla desde fuera hacia dentro, han recogido las entidades del mundo gnoseológico con la pretensión de empaquetarlas todas juntas en esa "memoria sui" agustiniana, creyendo que San Agustín quería enseñar el innatismo de las ideas. Considerémosla, al contrario, desde dentro hacia fuera, y admiremos la inmensa fuerza y maravillosa aptitud que Dios ha puesto amorosamente en su "imagen" al crearla; y comprendamos que si de hecho es capaz de sacar a su luz y entender verdades de suyo inconmutables y sin sujección al tiempo, es que su naturaleza también está más allá de los dominios de este tiempo.

Está nuestra alma más allá de los dominios del tiempo, y sin embargo, no es eterna. Expliquémonos. La idea del tiempo es algo

95. De Trin. XV, 13, 22, PL. 42, 1075-1076 
que suele introducir perplejidades en nuestros pensamientos; y es, que sin parar mientes en ello, se atribuye al tiempo una entidad de suyo, que sin saber cómo, antecede a todo ser, presidiendo su existencia. Pero no es así la nacuraleza de los hechos. El tiempo en cuanto representa algo, va siempre, como si dijéramos, a la zaga de algún ser. Nuestro tiempo ordinario, el tiempo en que se desarrolla nuestra vida en el mundo, no es otra cosa que el compás en que se desenvuelve la existencia del ente material, llevado por éste desde el centro de su propia esencia física. Puesto que vamos uncidos a la materia, nos arrastra la corriente de su tiempo; pero esto, sólo en la medida que somos materiales. El alma, la que es capaz de concebir visiones de la verdad inconmutable, es espiritual y no está sujeta al tiempo de la materia; ni su duración es sucesiva y fluente, como la propia de las entidades materiales. Si nosotros nos sentimos temporales a la manera de la materia, y no tenemos conciencia inmediata de la permanencia propia de nuestra esencia espiritual, mucho más excelente que la permanencia de la materia en su fluencia, es porque en esta vida no podemos ver directamente la "faz interna" de nuesira alma racional. Para verla, tendríamos que presenciar como espectadores la acción de Dios al crearnos, y esto no es posible por ahora.

Deducimos, pues, la inmortalidad del alma que no vemos, de las obras que le son propias y que vemos. Ahora bien; estas obras nos dicen que nuestra alma supera al tiempo de la materia; pero no nos dicen que le superan de manera que pueda inscribirse en la eternidad.

Para que un ser sea capaz de percibir verdades inconmutables, es preciso que su esencia entera se concentre en un "instante que no pasa". Ya se ve que ese "instante que no pasa" no cabe en el tiempo propio de la esencia del ente material, que se desarrolla en un flujo permanente. ¿Cómo podría reflejarse una verdad eterna en un ente de esta clase? Para que tal cosa suceda, se necesita una esencia espiritual que no se desgrana fluyendo. El modo de ser sin fluencia es lo que llamaron los escolásticos "eviternidad", propia de los espiritus creados. Permanencia eterna hacia adelante, pero no hacia atrás.

También los espiritus tienen su tiempo, aunque totalmente distinto del ciempo de la materia. En efecto, si es verdad que no tendrán fin, sin embargo, han tenido un comienzo por necesidad. Nuestra alma racional no tiene lo que "es" en virtud de su propio ser. $\mathrm{Y}$ esto, tenemos que decirlo, no porque de antemano hayamos asentado como por definición que la "faz interna" del alma es la acción del Creador constituyendo su esencia física; sino porque nos lo denuncian sin posible equivoco las obras propias del alma, su "faz externa", que está al alcance de nuestra experiencia reflexiva.

Es nuestro propio yo, nuestra "faz interna", la que hace y ex- 
perimenta sus obras, en especial las que comprende el círculo gnoseológico, y nos damos cuenta de lo imperfectas que son. No estamos satisfechos de nosotros mismos...; lo cual es indicio de que podemos llegar a ser más de lo que somos; pero también lo es, y mucho más cierto y apremiante, de que el ser que poseemos es deficiente en el propio orden del ser. Por consiguiente, no tiene de suyo la razón de su ser. El que tiene en sí mismo la razón de su ser, tiene ya por to mismo la plenitud del ser.

Por lo tanto, esa luz que lleva nuestro propio ser, aun cuando sea luz de eternidad y justamente por serlo, no se ha encendido por si misma; lo cual nos prueba que Dios tiene que existir. Debe haber un foco originario verdaderamente eterno del que nos viene la luz.

"En el interior del hombre habita la Verdad. Y si encuentras que tu naturaleza es mudable, trasciende sobre ti mismo; mas no olvides al trascenderte que te elevas sobre tu razón. Dirigete, pues, hacia el foco donde se enciende la luz de tu razón" "96.

Nosotros nos damos cuenta con certeza de que hay verdades que no están sujetas al tiempo, inconmutables de suyo e imperecederas. Pongamos como ejemplo el más sencillo entre los aducidos por San Agustín: "siete más tres son diez". No nos importa si esos tres o esos siete son manzanas o libros o cualquier otra cosa determinada. No nos interesa el contenido material de esa proposición lógica o de cualquier otra. Sólo nos interesa la verdad inmutable y permanente contenida en esa o en otra proposición lógica verdadera. La verdad lógica que en cuanto vista por nosotros, está físicamente en nosotros, y sin embargo, comprendemos perfectamente que también era verdad antes de existir nosotros, y lo seguirá siendo aunque nosotros dejemos de existir. Este es un hecho en verdad maravilloso: estamos en presencia de algo que "para nosotros" sólo existe cuando pensamos en ello con nuestros deleznables actos psíquicos. Es la verdad lógica existente para nosotros en nuestros procesos psicológicos. Mientras duran esos procesos momentáneos, por un lado, vemos que es verdad permanente y eterna, substraída de suyo a cualquier proceso temporal; $y$, por otro, que como cosa meramente lógica, no tiene existencia libre y de por sí. Luego, si es eterna y nosotros no podemos suministrarle el fundamento eterno que necesita, es preciso sin género de duda que haya una base subsistente de por sí, más arriba de nosotros, y que sea estrictamente eterna. Esa base eterna subsistente es Dios.

El argumento de San Agustín para probar y cerciorarse de que Dios existe, no tiene nada de ontológico en el sentido de que busque

\footnotetext{
96. In Interiore hominis habitat veritas. Et si tuam mutabilem inveneris, transcende et te ipsum. Sed memento cum te trascendis ratiocinantem animam te transcendere. Illuc ergo tende, unde ipsum lumen rationis accenditur. (De vera Religlone, 39, $72, \mathrm{PL} .34,154$ ).
} 
su fundamento en alguna suerte de visión directa de Dios. Sigue estrictamente el camino señalado por San Pablo "a creatura mundi". Sólo que busca entre las creaturas que están a nuestro alcance la que más claramente lleva en sí las huellas del Creador, que es nuestra propia mente racional. $\mathrm{Y}$ ve $\mathrm{y}$ comprueba en ella luces tan excelentes, que nos muestran de por sí directamente y sin más, que no pueden ser propiedad del alma en la oue lucen, y que necesitan un foco eterno originario totalmente inmutable $\mathrm{y}$ exento de todo residuo temporal. Y a la vez que deduce su existencia, comprueba la posibilidad de poseerle, puesto que ya en parte le tiene.

Es deductivo el argumento y concluyente, no porque de él saquemos al frente para verla la esencia de Dios; sino porque en él vemos vestigios que sólo pueden pertenecer a Dios. Deducimos, pues, la existencia de un SER perfecto en el orden del "ser" y estrictamente ETERNO: sin principio ni fin ni transcurso o fluxión de cualquier género. No vemos su Esencia; pero tampoco es para nosotros un abismo pavoroso absolutamente vacío, del que no podamos pensar absolutamente nada. Tenemos de El muchas noticias que nos dejó prendidas en todas sus creaturas; y podemos descifrar algunos signos suyos mientras vamos caminando hacia El, gracias a la luz que concentró en nosotros.

"Viendo, pues, y considerando todas las criaturas, quienquiera que camine hacia Ella, siente que la Sabiduría se le muestra sonriente, y le sale al encuentro en todas sus providencias...; El mismo camino le resulta hermoso gracias a aquella a la que se dirige anhelante" ${ }^{97}$.

"Ahi la tienes. Es la Verdad para ti. Abrázala, si puedes, goza de Ella y alégrate en el Señor" ${ }^{98}$.

\section{VICTOR DIAZ DE TUESTA}

97. Intuens ergo et considerans universam creaturam quicumque iter agit ad. sapientlam, sentit Sapientiam se sibi cstendere hilariter, et in omni providentia ocurrere sibi..., et ipsa vią per illam pulchra est, ad quam exaestuat pervenire. (De Lib. Arb. II, 17, 45, PL. 32, 1265).

98. Ecce tibi est ipsa Veritas: amplectere illam si potest, et fruere illa, et delectare in Domino. (1b. II, 13, 35, PL. 32, 1260). 